\title{
GEOLOGIC MAP OF THE MONTARA MOUNTAIN AND SAN MATEO $7-1 / 2$ QUADRANGLES, SAN MATEO COUNTY, CALIFORNIA
}

\author{
By Earl H. Pampeyan
}

\section{INTRODUCTION}

The Montara Mountain and San Mateo quadrangles span the San Francisco Peninsula and Santa Cruz Mountains in northern San Mateo County. The area covered by this geologic map extends from precipitous cliffs and flat marine terraces along the Pacific Coast, eastward across rugged topography, to gently sloping alluvial plains and tidal and marsh lands of San Francisco Bay. The rugged topography is cut by several northwest-trending linear trenches, the two most prominent of which are along the San Andreas and Pilarcitos Faults. The map and adjoining areas are divided into four structural blocks juxtaposed along major faults (fig. 1), adopting the scheme of Nilsen and Brabb (1979): the San Francisco Bay block lying east of the San Andreas Fault; the Pilarcitos block lying between the San Andreas and Pilarcitos Faults; the La Honda block lying between the Pilarcitos and Seal Cove-San Gregorio Faults; and the Pigeon Point block lying west of the Seal Cove-San Gregorio Fault. In this area the Pilarcitos Fault marks the boundary between Salinian granitic basement of the La Honda and Pigeon Point blocks and Franciscan Complex basement of the Pilarcitos and San Francisco Bay blocks, each of which is overlain by Cenozoic coarse- to fine-grained clastic sedimentary units. On the geologic map the San Andreas, Pilarcitos, and Seal Cove Faults are indicated by a single line representing the most prominent and most recently active trace in the respective zones of faulting.

Most of the bayside flatland area has been covered with residential and commercial developments so that only vestiges of historic alluvial deposits and tidal and marsh lands remain. San Andreas and Crystal Springs Lakes are man-made reservoirs in San Andreas and Crystal Springs Valleys, and Pilarcitos Lake is a man-made reservoir on Pilarcitos Creek. These lakes and the surrounding watershed lands are part of the water supply system for the city and county of San Francisco. The watershed, also a state fish and game refuge, is largely undeveloped except for facilities of the San Francisco Water Department. The coastal side of the San Francisco Peninsula contains openspace land as well as pockets of dense urbanization, but development there has been limited by poor access, inadequate utility facilities, and California Coastal Zone restrictions. Municipalities in the map area include Pacifica, San Bruno, Millbrae, Burlingame, Hillsborough, San Mateo, Foster City, Belmont, San Carlos, Redwood City, and unincorporated districts of Montara, Moss Beach, and El Granada (fig. 2).

Geologic maps of all or parts of the present map area have been prepared by Lawson (1914), Glen (1959),
Darrow (1963), McLaughlin (1969), Jack (1969), Pampeyan (1975; 1981a, b), Helley and others (1979), Morgan (1981a), and numerous researchers studying topical stratigraphic, geologic, and geotechnical problems. In addition, a series of maps prepared in cooperation with the county of San Mateo and based on the geologic map of San Mateo County (Brabb and Pampeyan, 1983) include the present map area. The interested reader is referred to Brabb and others (1982), Brabb (1983), Wieczorek and others (1985), Thomson and Evernden (1986), Brabb and Olson (1986), Youd and Perkins (1987), Perkins (1987), and Mark and Newman (1988) for information pertaining to history, slope stability, seismic shaking, liquifaction potential, and faulting and seismicity in the county. For information on physical and engineering properties of the map units the reader is referred to Wentworth and others (1985).

Field work for this geologic map was done in 19701973 and 1980 (Pampeyan, 1981a, b). Some minor additions and revisions were made in 1982, but numerous changes caused by post -1980 grading operations in connection with urban development are not shown.

\section{STRATIGRAPHY}

\section{PRE-CRETACEOUS ROCKS}

The oldest(?) rocks present in the map area are small pendants of metasedimentary rock (unit $\mathrm{pKm}$ ) in the granitic rock of Montara Mountain (unit $\mathrm{Km}$ ). One pendant near the south-central edge of the map area, is marble; the other pendants, near the south edge of the map area in El Granada, consist of three lenses of schist and hornfels. No other pendants were seen in the granitic terrane, although others may be present beneath the mantle of surficial deposits. Lawson (1914) correlated the marble with the Paleozoic(?) Gabilan Limestone in Monterey County, a dubious correlation at best. Lacking diagnostic data, the pendants are considered to be remnants of a pre-Cretaceous sedimentary unit.

\section{JURASSIC AND CRETACEOUS ROCKS}

Sedimentary and igneous rocks of the Franciscan Complex, most of which are metamorphosed to some degree, are the next oldest units in the map area, and they form the basement of the Pilarcitos and San Francisco Bay blocks. They are considered to be Jurassic and Cretaceous in age though no Jurassic index fossils are known from this area. In the Pilarcitos block the dominant Franciscan units are greenstone (unit $\mathrm{fg}$ ) and sandstone (graywacke) (unit fs), with a band of sheared rock (unit fsr) along the Pilarcitos Fault. Limestone. 


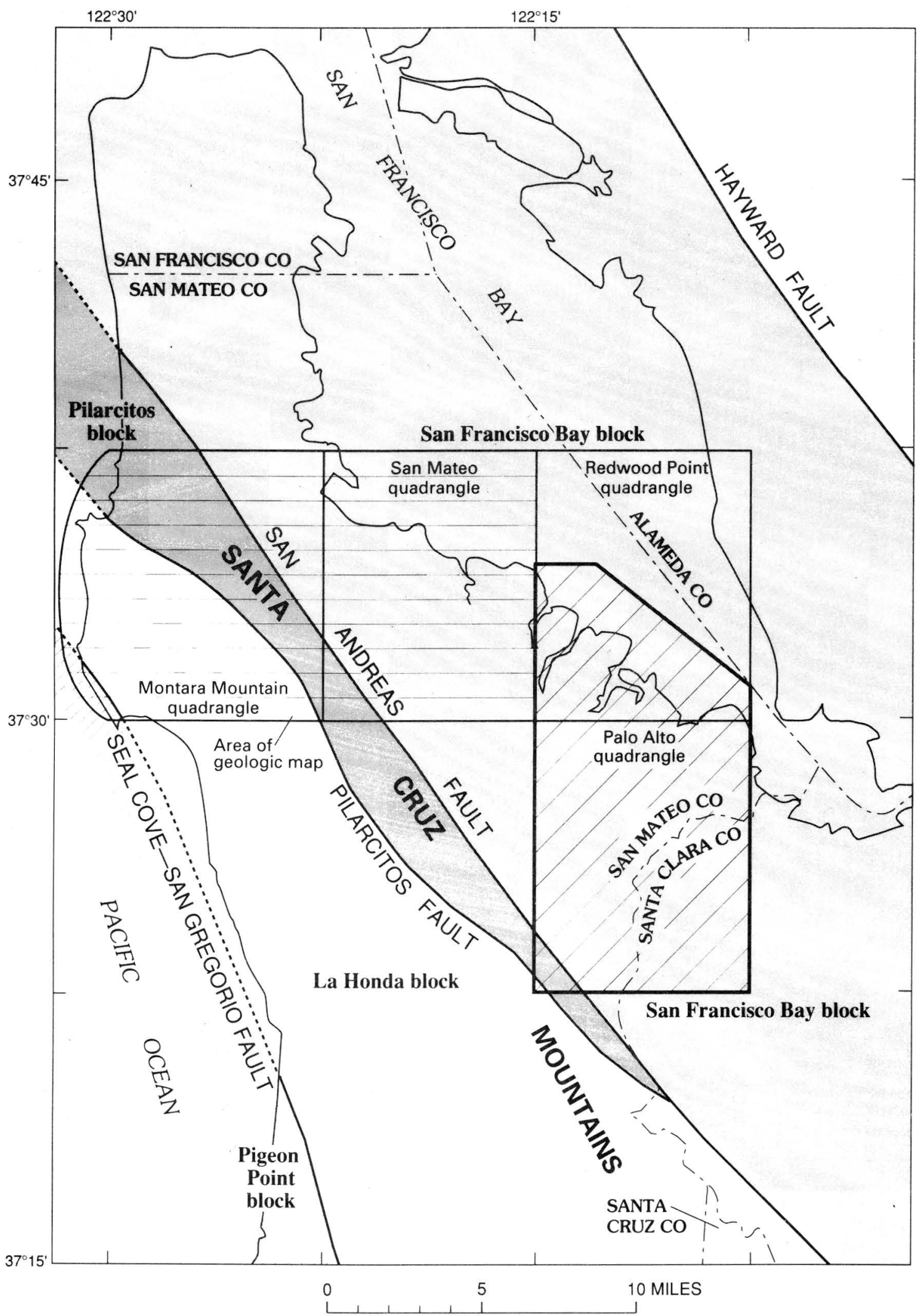

Figure 1. Map showing relation of study area (horizontal lines) to major tectonic boundaries of the northern Santa Cruz Mountains. Diagonal-lined area is Palo Alto and part of the Redwood Point quadrangles (Pampeyan, 1993). 


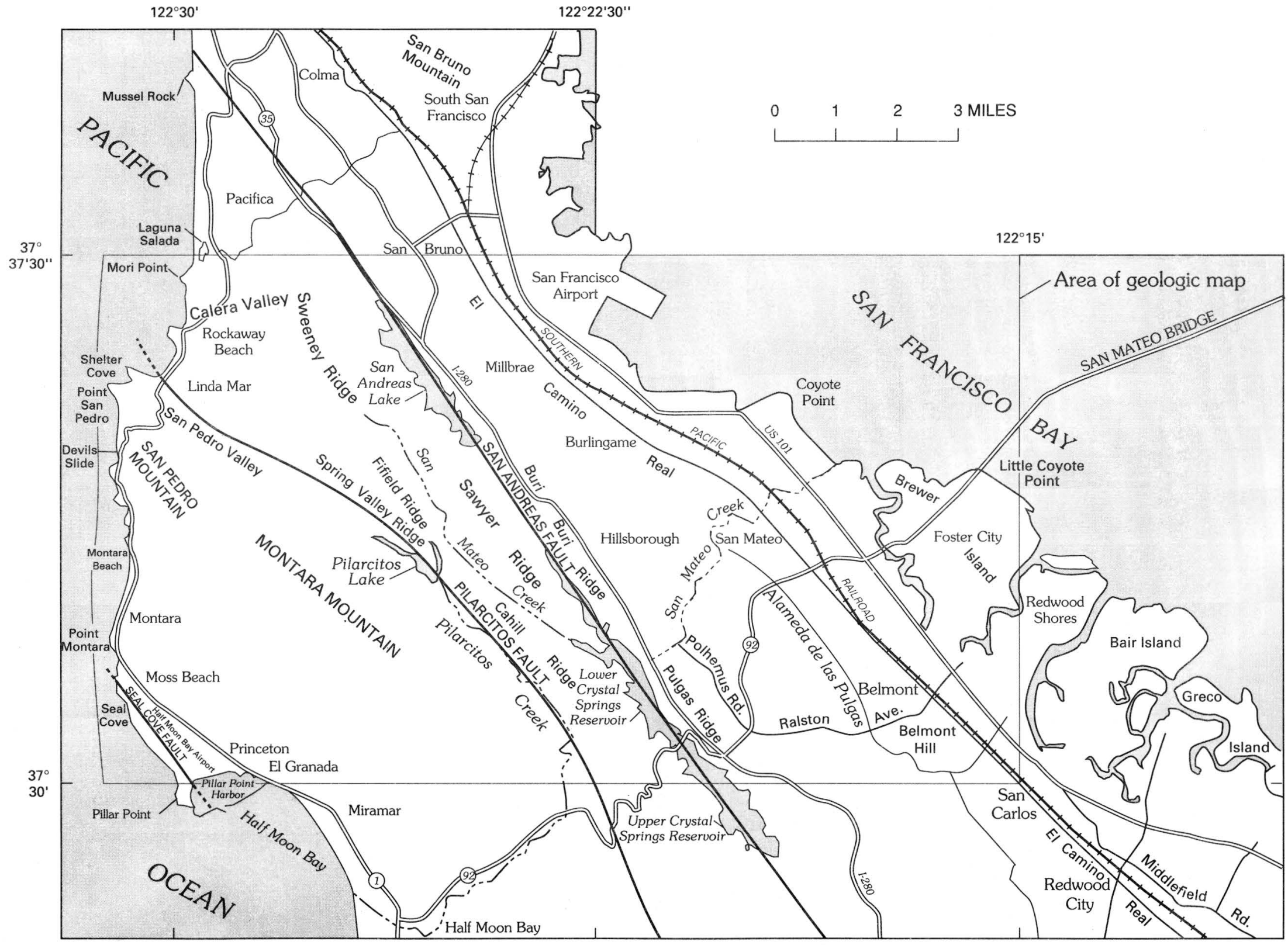

Figure 2. Geographic map of study area and vicinity. 
serpentinite, conglomerate, chert, and glaucophane schist, in decreasing order of abundance, also are present. Greenstone in the northern part of the map area is largely agglomerate, flow-breccia, and tuff; in the southern part of the map area, greenstone consists of flows with or without pillow structure. The greenstone unit appears to be interbedded with graywacke, though the structure may be more complex than described by Lawson (1914). In the San Francisco Bay block, sheared rock (unit fsr) of the Franciscan Complex is the dominant unit. It contains tectonic inclusions of greenstone, graywacke, glaucophane schist, and chert scattered about in random fashion. Along the east edge of the sheared-rock unit, coherent bodies of chert, graywacke, and conglomerate are present; along its southwest edge the sheared rock unit is covered by serpentinite.

Sandstone (unit $\mathrm{fs}$ ) of the Franciscan Complex, commonly referred to as graywacke, is widespread in the Pilarcitos block where it appears to be interbedded with predominantly pyroclastic greenstones. In the San Francisco Bay block the largest bodies of coherent graywacke border the flatlands between San Carlos and San Mateo. Tectonic inclusions of graywacke present in the sheared rock unit are relatively small and not easily recognized as such in natural exposures. One unique tectonic inclusion of graywacke exposed during construction of Highway 92 near the College of San Mateo contained seams of anthracitic coal 2 in. thick (G.O. Gates, oral commun., 1970).

Northeast of Belmont Hill, between El Camino Real and Highway 101, a small hill underlain by conglomerate, chert, and greenstone was the site of U.S. Coast Survey (1853b, 1857b) triangulation station ANGELO. Lawson (1914) believed that this conglomerate, and another small patch of conglomerate a half mile southwest of Belmont Hill, probably represented the Knoxville Formation. The small hill, later referred to as Quarry Hill, was removed by grading about 1951 but exposures of pebble to cobble conglomerate (unit $\mathrm{fcg}$ ) remain and undoubtedly are part of the Franciscan Complex. The small patch of conglomerate to the southwest consists of well-rounded chert pebbles in a silty to clayey matrix and resembles chert-pebble conglomerate lenses and beds in Franciscan graywackes on Belmont Hill, exposures of which were too poorly exposed to determine their total extent. Cobble conglomerate similar to that at ANGELO is present along the north edge of San Pedro Valley in the Linda Mar district of Pacifica and, though poorly exposed, extends for about a mile either as a single thin block in sheared rock or as five more or less aligned northwest-trending detached elongate blocks. The conglomerate at ANGELO is composed of weathered cobblesize clasts in a graywacke matrix, and at Linda Mar the conglomerate is lithologically similar except that locally it contains some small-boulder-size clasts.

Altered mafic volcanic rock is widespread in the Pilarcitos block and scattered about in the San Francisco Bay block. This rock type, referred to as greenstone, is composed mostly of coarse pyroclastic ejecta but also contains small intrusive plugs and flows locally showing pillow structures. Lawson's (1914) map shows basaltic rock on Belmont Hill which he correlated with Miocene volcanic rock to the south in the adjoining Santa Cruz 30' quadrangle (Haehl and Arnold, 1904; Branner and others, 1909). The basaltic rocks that I saw on Belmont Hill had no lithologic resemblance to Miocene basalt to the south (Pampeyan, 1970, 1993) or elsewhere in San Mateo County (Brabb and Pampeyan, 1983), they were Franciscan greenstone.

Rhythmically bedded, grayish-red to dark-brown radiolarian chert interlayered with graywacke and greenstone is well exposed in San Carlos, Belmont, central San Mateo, and at Coyote Point. There are other moderate-size exposures of chert, most of which are tectonic inclusions in sheared rock. Many of the remaining smaller bodies are yellowish-orange, grayish-green, or white, and some of them are recrystallized and have fractures and voids up to a few inches across lined with quartz crystals. Radiolarians from shale interbeds at the site of ANGELO were described by Riedel and Schlocker (1956) as having similarities with some Jurassic and Cretaceous species, and a Jurassic or Cretaceous age was postulated for this fauna by Bailey and others (1964).

Limestone bodies extend diagonally southeast across the map area and, with one exception, are all in the Pilarcitos block The largest body was at Rockaway Beach at the mouth of Calera Valley, which Lawson (1914) defined as the type Calera Limestone Member of the Cahil Sandstone. More recent reports have revised the Calera as a separate formation (Brabb and others, 1982). Little of the type Calera Limestone outcrop remains today owing to quarrying operations in the area. Much of the remaining limestone is interbedded with graywacke and greenstone, and some is surrounded by sheared rock (unit $\mathrm{fsr}$ ). Along the west edge of Lower Crystal Springs Reservoir, many of the small bodies of limestone are elongate parallel to the San Andreas Fault; these bodies appear to be fault slivers, but outcrops typically do not expose details of the contact with enclosing rocks. According to W.V. Sliter (oral commun., 1991), foraminifers from the type locality of the Calera indicate an Aptian to Cenomanian (mid-Cretaceous) age, similar to limestone in the Permanente quarry $30 \mathrm{mi}$ southeast across the San Andreas Fault (Tarduno and others, 1991), except that at the quarry the section extends upward into the Turonian Stage. Rare megafossils from Franciscan rocks in San Francisco (north of map area) and at New Almaden (south of map area) also indicate a mid-Cretaceous age (Bailey and others, 1964). A lone small body of palered limestone seen in the San Francisco Bay block near the head of Mills Creek in San Mateo, believed to be in its natural setting, lithologically resembles the informally named Laytonville limestone of Alvarez and others (1980) (equivalent to the Laytonville-type limestone of Bailey and others, 1964) of the Franciscan Complex of northern California, but the correlation is not well enough established to extend the unit name to the area of this map.

Tectonic inclusions of metamorphic rock typically surrounded by sheared rock or serpentinite are present in the San Francisco Bay block, but are not restricted to the sheared rock and serpentinite units. The inclusions represent the blueschist metamorphic facies and have schistose to gneissic textures. Some inclusions are 
as large as $30 \mathrm{ft}$ across but most are much smaller. Inclusions of blueschist also are present in sheared rock north of San Pedro Valley, but they are too small to show on the map.

Sheared rock (unit fsr), or mélange (Hsu, 1968), is the predominant Franciscan unit of the San Francisco Bay block, and it also underlies a significant part of the Pilarcitos block. Excellent outcrops of this unit were exposed during construction of Highway 92 between San Mateo and Interstate 280. The unit consists of blocks or tectonic inclusions of graywacke, greenstone, chert, glaucophane schist, and limestone in a sheared mudstone matrix. Sinear foliation in this unit typically is horizontal or shallowdipping in contrast to vertical shear foliation in the San Andreas Fault Zone. North of San Pedro Valley and in places northwest of Buena Vista School (between Parrott Drive and Polhemus Road), this unit is deeply weathered and erodes to badlands topography. Cowan (1985) proposed a four-fold classification scheme for mélanges: I, disrupted sandstone and mudstone strata; II, disrupted thin beds of chert, greenstone, and minor sandstone originally interbedded with mudstone; III, block-in-matrix mudstone chaos, inclusions of diverse shapes, sizes, and compositions in a mudstone matrix; and IV, lenticular inclusions of diverse types bounded by an anastomosing network of faults. Sheared rock of the San Francisco Bay block matches the description of type III mélange and those of the Pilarcitos block appear to grade from type I to III. The contact between sheared rock and uninterrupted Franciscan units in the San Francisco Bay block is at least locally interpreted as a high-angle fault. Exposures of this contact in urbanized areas of the map area are poor, but they plot as curvilinear boundaries which may indicate low-angle faults. In the Pilarcitos block the north edge of the sheared rock unit is irregular-possibly the result of repetition along high-angle faults parallel to the Pilarcitos Fault. Origin of mélanges and their relation to the west edge of the North American Plate is discussed in detail by Fox (1983).

Serpentinite is widespread in the San Francisco Bay block where it occurs predominantly in a large flat-lying to gently west dipping sheet overlying sheared rock and also as near-vertical lenses and pods. The sheet dips down to the San Andreas Fault Zone where it terminates, and the lenses generally parallel the San Andreas Fault. Serpentinite is less abundant in the Pilarcitos block where it occurs mainly as lenses along faults and locally as pods in sheared rock. Lawson $(1895,1914)$ considered the lenticular bodies to be dikes and the large serpentinite sheet to be an unroofed laccolith, but Fairbanks (1897) argued that the sheet was a sill instead of a laccolith. The steeply dipping lenticular bodies may be remnants of serpentinized ultramafic fault-controlled dikes, but some are randomly oriented tectonic inclusions in sheared rock. The large sheet of serpentinite, rather than being an intrusive body, may have flowed from a fissure onto an erosion surface as described by Carlson (1984) elsewhere in the Coast Ranges and subsequently been truncated by the San Andreas Fault.

In a few places the serpentinite has been hydrothermally altered to silica-carbonate rock (unit sc). Lawson (1914) noted one large body a half mile east of Crystal
Springs Dam, and evidence of its presence exists even after urban development of the area. Other small occurrences of silica-carbonate rock are present in the map area; all but two, one $0.8 \mathrm{mi}$ west-northwest and the other $1.9 \mathrm{mi}$ southeast of Crystal Springs Dam, are too small to show on the map. In the California Coast Ranges, mercury deposits commonly occur in silica-carbonate rock, and stratigraphic relations indicate that the mineralization that produced the silica-carbonate rock and associated mercury deposits is related to middle Tertiary (late Miocene or younger) volcanism (Bailey and others, 1964). No metallic sulfide minerals were seen in the silica-carbonate-rock.

On the geologic map two areas are shown as metaigneous and metasedimentary rocks, undivided (unit fu) of the Franciscan Complex. One is on Buri Buri Ridge, where landscaping and grading for the Crystal Springs Golf Course have obscured bedrock relations, and the other is on the southwest slope of Cahill Ridge, where outcrops of Franciscan rocks are inaccessible or too poorly preserved to assign to a specific lithologic unit. The geology of these areas may be as straightforward as shown by Lawson (1914) but present-day exposures indicate a more complex distribution of units.

In his report on the San Francisco Bay region Lawson (1914) divided the Franciscan rocks of this area into formations, for example, the now abandoned Cahil Sandstone and Sausalito Chert. His Cahil Sandstone consisted of graywacke and included the Calera Limestone Member along with small lenses of chert and limestone. $\mathrm{He}$ correlated the large chert bodies around Belmont with his Sausalito Chert in Marin County and relegated smaller chert bodies and lenses to the Cahil Sandstone. He made no mention, however, of the random distribution of chert, greenstone, limestone, and metamorphic rock bodies in a comminuted matrix of shale and graywacke and mapped those areas as the Cahil Sandstone.

\section{CRETACEOUS ROCKS}

Basement rock of the La Honda and Pigeon Point blocks is granitic, but is so pervasively fractured that sound hand specimens representative of the unit are difficult to obtain. Narrow aplite and pegmatite dikes are common, and in a few places buff-weathering rhyolite dikes as wide as $2 \mathrm{ft}$ are present. The granitic rock of Montara Mountain has been variously called granite (Lawson, 1893, p. 150; Lawson, 1895 , p. 8), quartz diorite (Branner and others, 1909; Lawson, 1914, p. 4; Curtis and others, 1958, p. 9; Compton, 1966, p. 285; Ross, 1972, p. 10), granodiorite (Darrow, 1963, p. 9-11), and tonalite (Ross, 1984, figs. 4, 6), the differences largely reflecting the nature of study and the choice of classification scheme. Most workers agree, however, that the ratio of potassium feldspar to plagioclase varies from place to place within this pluton. Modal analysis of $22 \mathrm{me}$ gascopically identical specimens by Ross (1972) and 25 specimens from this study, using the classification scheme of Streckeisen (1973), showed the composition to range from tonalite to granite (fig. 3). With the exception of dike rocks and one locality $1 \mathrm{mi}$ east of South Peak where coarsely crystalline felsic rock contains some pyrope(?) garnet, all exposures of this pluton contain an abundance 
of hornblende and biotite. Foliation in the pluton is steep and is indicated by orientation of mafic minerals, tabular dioritic inclusions, and dikes; strike of the foliation ranges from northeast to northwest. Potassium-argon age determinations on two samples of granitic rock (California Division of Mines and Geology, 1965; Curtis and others, 1958; Compton, 1966), recalculated using 1977 constants (Steiger and Jager, 1977), yielded ages of 88.4 and 89.6 Ma. Fission-track analyses of two samples (Naeser and Ross, 1976) yielded ages of 81.7 and $84.1 \mathrm{Ma}$ on sphene and $23.1 \mathrm{Ma}$ on apatite. According to Compton (1966), Evernden and Kistler (1970), and Naeser and Ross (1976) the resultant ages do not represent time of intrusion of the pluton but the time of subsequent deformational or heating events.

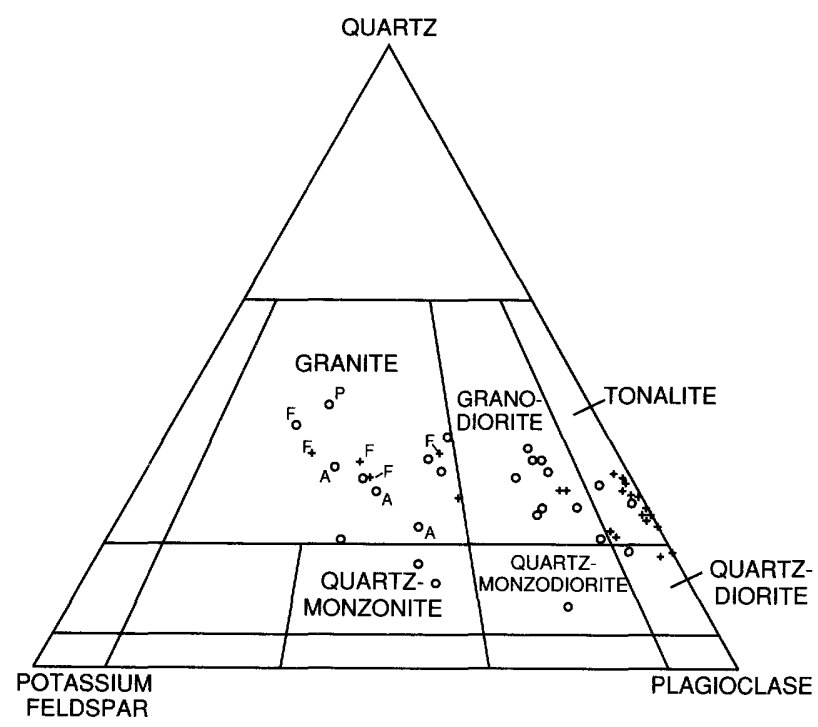

Figure 3. Modal analyses of igneous rocks of Montara Mountain classified after Streckeisen (1973). A, aplite; $\mathrm{P}$, pegmatite; F, felsic rocks; +, Ross (1972); o, this study.

\section{PALEOCENE ROCKS}

Overlying the granitic basement rock is a sequence of Paleocene turbidite deposits first considered to be part of the Franciscan Series (Lawson, 1895) and then tentatively assigned to the lower Eocene Martinez Formation (Lawson, 1914). Darrow (1963) divided the sequence into lower (Cretaceous) and upper (Paleocene) units along a boulder conglomerate bed at the base of the upper unit, and subsequently the Cretaceous designation was changed to Paleocene on the basis of Ynezian fossils found in upper and lower units (Morgan, 1981a). Studies by Nilsen and Yount (1981) and Morgan (1981a, b) refined the stratigraphy of the sequence, and Morgan (1981a) divided the sequence into three members. On this map the turbidite sequence of sandstone, shale, and conglomerate is divided into lower (unit TsI) and upper (unit Tsu) parts corresponding to Darrow's (1963) units, along the contact between Morgan's (1981a) lowest and middle members.
The sequence is folded and faulted and the base of the lower part is not exposed. The lowest exposures crop out between Point San Pedro and the north point of Shelter Cove and consist mostly of alternating turbitite sandstone and shale beds. The basal boulder conglomerate of the upper part (unit Tsu) is channeled into the lower part and is well exposed along the east-west part of Highway 1 . The largest clasts in the conglomerate there appear to be derived from the granitic rock of Montara Mountain, but other clasts are derived from the Franciscan Complex. On San Pedro Mountain, pebble to cobble conglomerate in contact with granitic rock is believed to represent the basal part of the upper part (unit Tsu) (Morgan, 1981b). The conglomerate section appears to thin northward from about $300 \mathrm{ft}$ on San Pedro Mountain to about $4 \mathrm{ft}$ (Darrow, 1963) at Point San Pedro. Sheared and brecciated rocks along the contact between conglomerate and underlying granitic rock indicate that muchif not all - of this contact is a fault. Above the conglomerate is a sequence of turbidite sandstone and shale that contains some carbonate beds. Most of the carbonate beds are composed of detrital grains, but some beds are composed of secondary carbonate replacing feldspar and quartz grains (Morgan, 1981a, b; Nilsen and Yount, 1981). Locally the carbonate beds have an aggregate thickness of about $10 \mathrm{ft}$. No carbonate beds are known from the lower part (unit Tsl). Morgan (1981a, b) and Nilsen and Yount (1981) provide details on the petrology, paleontology, and sedimentology of this sequence of Paleocene rocks. In the sea cliff at Devils Slide, slope failures in the sandstone and shale turbidite deposits cause periodic closure of Highway 1.

\section{EOCENE(?) ROCKS}

At the south edge of the map area, $1 \mathrm{mi}$ west of Carlmont High School, a small patch of unnamed sandstone (Ta) rests on graywacke of the Franciscan Complex. This unit was mapped by McLaughlin (1969) as unnamed Eocene(?) arenite, an outlier of lithologically similar rocks present a mile to the southeast. Although these rocks are coarser-grained, they may possibly be the temporal equivalent of Eocene sedimentary rocks $5 \mathrm{mi}$ southeast in Redwood City mapped as the Whiskey Hill Formation (Beaulieu, 1970, 1971; Pampeyan, 1993).

\section{OLIGOCENE AND (OR) MIOCENE ROCKS}

Rocks assigned to the Mindego Basalt (unit Tmi) are present in a wedge-shaped fault block at the south edge of the map area, between granitic rock and the Franciscan Complex. In the map area this unit is a wacke containing mafic volcanic rock fragments, and it interfingers southward with basaltic rocks mapped by Brabb and Pampeyan (1983) as the Mindego Basalt. In roadcuts along Highway 92, half a mile south of the map area, this unit is mostly weathered amydaloidal basaltic lava with small amounts of interlayered conglomerate.

\section{PLIOCENE ROCKS}

Sedimentary rocks (unit $T p$ ) exposed in the Seal Cove Bluffs and wave-cut bench from Moss Beach south to Pillar Point (fig. 2) were mapped as the Merced Forma- 
tion by Lawson (1914) and later reassigned to the Purisima Formation by Glen (1959). Glen's correlation was based on lithologic and faunal similarities between his Pillar Point "Merced" Formation and the type Purisima (Haehl and Arnold, 1904), about $9 \mathrm{mi}$ to the southeast. In the map area the bulk of this unit is fine grained and lies southwest of the main trace of the Seal Cove Fault where neither its base nor its top are exposed. Northeast of the fault, however, in the east limb of the Moss Beach syncline, the basal part of the unit is exposed and consists of boulderto pebble-conglomerate beds resting nonconformably on granitic rock. The northernmost exposure of Purisima beds is in the sea cliff $0.5 \mathrm{mi}$ south of Point Montara lighthouse where a northeast-striking vertical fault separates sandstone from granitic rock. Glen's (1959) correlations, along with later information on sense of movement in the Seal Cove-San Gregorio Fault Zone, indicate the Purisima of the Seal Cove Bluffs has been offset laterally northwest an unknown distance from rocks of the type locality of the Purisima Formation across the Seal Cove-San Gregorio Fault.

Glen's (1959, p. 164) study dated the Purisima Formation in this area as "...middle or perhaps even early Pliocene...". Cummings and others (1962) correlated these rocks with the (lower and upper Pliocene) Pomponio Member of the Purisima Formation, and Addicott (1969) showed them as early Pliocene in age. Marine fauna of the type Purisima indicate the unit is early to late Pliocene in age (Cummings and others, 1962; Addicott, 1969). Vertebrate fossils were found in the Purisima Formation on the wave-cut bench at Moss Beach in 1970 by Evelina Dunton of San Mateo and between Moss Beach and Seal Cove in 1965 by Richard Pefley of Montara. Dunton found a walrus radius indicating a probably early Hemphillian age (about $7 \mathrm{Ma}$ ), and Pefley found a porpoise skull indicating a Hemphillian age (7-5 Ma) according to C.A. Repenning (written commun., 1989).

Exposures of the Merced Formation (unit Tme) are continuous southeastward from its type section in the San Francisco South quadrangle (Lawson, 1914; Bonilla, 1971a) to the vicinity of Burlingame and discontinuous as far south as Hillsdale Boulevard in San Mateo-both in and east of the San Andreas Fault Zone. Sandstones of the Merced Formation have a distinctive texture and yellowish color in natural outcrop and are not usually confused with weathered Franciscan graywacke or strata of the Colma Formation. The lower contact with Franciscan rocks is exposed in several places as is the upper contact with the overlying Colma Formation. A complete section, however, was not recognized in the map area, nor were marker beds with which a composite section could be constructed. Faulted and folded beds east of San Andreas Lake suggest the Merced Formation may be as much as $500 \mathrm{ft}$ thick in the map area. Molluscan fossils common in the map area indicate a late Pliocene age. At its type locality, about $4 \mathrm{mi}$ north of this map area, the Merced is more than 5,000 ft thick and contains Pleistocene fossils in its upper part (Hall, 1966) as well as an ash bed correlated with the 400,000-yrold Rockland ash bed (Sarna-Wojcicki and others, 1985). The Pleistocene part of the Merced was not recognized in the map area.

\section{PLEISTOCENE ROCKS AND DEPOSITS}

The Colma Formation (unit Oc) underlies much of the historic alluvial plain southeast from San Bruno, at least as far south as Burlingame and possibly to San Mateo. Natural exposures are uncommon in most of the area, but in a few exposures bedding appears to dip less than $10^{\circ}$; a few dips as steep as $35^{\circ}$ are probably on foreset beds, which were better exposed in the San Bruno area north of this map area (Bonilla, 1971a). The Colma Formation is overridden by rocks of the Franciscan Complex and Merced Formation in the Serra Fault Zone but appears no more deformed there than in scarce exposures elsewhere. In places the main criteria for separating the Merced from the Colma was the steeper bedding planes in the Merced. I saw no fossils in the Colma Formation, but in 1962 M.G. Bonilla collected a sea cow rib and other bone fragments from a locality in San Bruno about $300 \mathrm{ft}$ east of the trace of the Serra Fault at what is now the intersection of Jenevein Avenue and Interstate 280 , a locality destroyed during construction of Interstate 280. At that time he questionably assigned the fossil-bearing beds to the Merced Formation. C.A. Repenning (written commun., 1989) believes these bones indicate a "...Clarendonian (8-12 Ma) or Hemphillian..." (middle to late Miocene) age, an age range much older than that of the fossiliferous upper Pleistocene Colma Formation or upper Pliocene Merced Formation in this area. In the late 1920's a creek-bank exposure of 5 to $10 \mathrm{ft}$ of blue-gray sand containing lignitic seams, logs, cones, and seeds, overlain by 15 to $20 \mathrm{ft}$ of brownishyellow pebbly sand, was found in San Bruno. This locality, surrounded by deposits of the Colma Formation, is very close to Bonilla's vertebrate locality, and the plant fossils were determined to be Pleistocene in age (Potbury, 1932). It is likely that the sea cow bones were reworked from older deposits or that they represent a block of older deposits in the Serra Fault Zone.

Poorly indurated and poorly sorted alluvial deposits assigned to the Santa Clara Formation (unit Os) are present west of the 1906 trace of the San Andreas Fault at the south edge of the map area. A smaller body occurs as a fault sliver east of the 1906 trace half a mile northwest of Crystal Springs Dam. Both bodies have smiliar compositions with the exception of the presence of glaucophane schist boulders in the northern body. Cummings (1968) divided the Santa Clara Formation into eight lithofacies in his regional study and showed his Crystal Springs facies I at the south edge of the San Mateo quadrangle (Cummings, 1972). He distinguished his Crystal Springs facies II from his facies I on the basis of exotic rock types in an otherwise lithologically similar unit, and he deduced that the Franciscan source for these deposits was east of the San Andreas Fault. The fault sliver of the Santa Clara Formation, though not shown by Cummings $(1968,1972)$, may be part of his Crystal Springs facies II displaced from the main mass of facies II strata along a separate strand of the San Andreas Fault.

The Santa Clara Formation is generally considered to be late Pliocene and early Pleistocene in age in its type area at Saratoga, about $22 \mathrm{mi}$ southeast, on the basis of plant and animal fossils found there (Sorg and 
McLaughlin, 1975; Adam and others, 1983). In the Palo Alto $7-1 / 2$ quadrangle, about $10 \mathrm{mi}$ southeast of the map area, the Santa Clara Formation rests on fossiliferous upper Pliocene strata of the Merced(?) Formation (Pampeyan, 1970, 1993) and is thought to be late Pliocene and early Pleistocene in age (Vanderhurst and others, 1982). Near Woodside, about $6 \mathrm{mi}$ southeast of the map area the Santa Clara Formation contains an ash bed identified by Sarna-Wojcicki and others (1985) as the 400,000-yr-old Rockland ash bed. Cummings (1972) shows the Crystal Springs facies I and II as overlying his Woodside facies in which the ash bed occurs, implying that the Crystal Springs facies I and II are late Pleistocene in age. In the type section of the Merced Formation the 400,000-yr-old ash occurs in beds assigned to the Pleistocene upper member of the formation (Glen, 1959; Hall, 1966). It appears, therefore, that the Santa Clara Formation transgresses the Pliocene-Pleistocene boundary northward along the San Francisco Peninsula and possibly intertongues with the Merced Formation, its temporal marine equivalent (Addicott, 1969).

Several levels of marine terraces or wave-cut benches are visible along the Pacific Coast. Smith (1960) summarized information from early coastal terrace studies and within the map area grouped the terraces into Half Moon Bay and Mussel Rock sequences. In addition, he described a Colma terrace sequence on the east side of the San Francisco Peninsula. The Half Moon Bay and Mussel Rock sequences are equivalent, but their continuity along the coast is interrupted by Montara Mountain. According to Smith (1960) the Colma terrace sequence, which extends from the vicinity of Colma to Belmont, was formed contemporaneously with the Half Moon Bay-Mussel Rock sequence. A detailed study of the marine terraces between Montara Beach and Princeton by Jack (1969) refined the stratigraphy and structure of the coastal terrace sequence. Along the Pacific coast the first emergent terrace, Half Moon Bay-Mussel Rock of Smith (1960), and second terrace, Miramar of Smith (1960) or Montara of Jack (1969), are well developed and easily recognizable; on the San Francisco Bay side of the peninsula, however, the Colma terrace sequence has been obliterated or obscured by urban development. Other probable wave-cut surfaces exist as high as 900 $\mathrm{ft}$ above sea level on the southwest-facing slopes of Montara Mountain, and sub-horizontal erosion surfaces at 1,000$1,100,1,300$, and $1,600 \mathrm{ft}$ above sea level northeast and east of El Granada may represent still older marine terraces. Marine terrace deposits are continuously present along the coast from south of El Granada to Montara Beach and discontinuously north from Calera Valley. Deposits on the lowest (youngest) or Half Moon Bay terrace extend from well south of El Granada to Point Montara where they are faulted against older deposits on the Montara terrace (Jack, 1969). The Seal Cove Bluffs, west of Half Moon Bay Airport, are capped with deposits of the lowest terrace, uplifted as much as $148 \mathrm{ft}$ along the Seal Cove Fault (Kennedy and others, 1982). Deposits on the Mussel Rock terrace are poorly exposed around Laguna Salada and in Calera Valley and may also exist in San Pedro Valley beneath Holocene beach deposits and artificial fill.
Deposits on the second or Montara (Miramar) terrace are well exposed along Montara Beach and highway cuts and sea cliffs in Montara. The Montara deposits are predominantly derived from the underlying granitic rock, and the younger Half Moon Bay deposits are mainly reworked Montara deposits (Jack, 1969). At the south end of Montara Beach a down-faulted remnant of still older terrace deposits is exposed-part of the San Vicente terrace of Jack (1969). Franciscan rock-types, especially well-rounded chert pebbles, are common in these older deposits, isolated remnants of which are recognized at 550-600 ft above sea level north of Princeton (Jack, 1969) and $500-725 \mathrm{ft}$ above sea level northeast of Princeton. On this geologic map, all the coastal marine terrace deposits are shown as a single unit $(\mathrm{Omt})$.

Marine invertebrate fossils from the Half Moon Bay terrace deposits have been dated by amino acid racemization methods at 80,000 to 85,000 yr B.P. (Kennedy and others, 1982). Local and regional studies suggest that the Montara (Miramar) terrace deposits may be about 325,000 years old (K.R. Lajoie, oral commun., 1991) and the highest deposits considerably older. C.A. Repenning (written commun., 1989) reports that in 1980 Oliver Espey of Montara found Smilodon (saber-tooth tiger) and Mammuthus (mammoth) bones on Montara Beach $0.3 \mathrm{mi}$ south of Martini Creek. This locality, at about mean sea level and often covered by beach sand, may be in a remnant of the Montara terrace. According to Repenning the fossils are probably less than 400,000 years old. Discoveries of mammoth bones in San Mateo, Millbrae, and near Half Moon Bay and bison bones in Pilarcitos Creek previously were assigned to the Pleistocene by Hay (1927). Specific details on the first three localities are not given; the fourth locality is given as about $600 \mathrm{ft}$ upstream from Pilarcitos Lake dam, at a depth of $21 \mathrm{ft}$, where blue clay was being dug for use in the core of the dam (Hay, 1927, p. 121-122). The San Vicente terrace deposits have not been dated.

Pleistocene coarse-grained fan deposits (unit Qoa) are found along the foothills between San Mateo and San Carlos sloping gently northeast and locally extending headward into drainages cutting through the foothills. This unit has been mapped around the edges of San Francisco Bay (Helley and Lajoie, 1979). In the Palo Alto (Pampeyan 1993) and Mountain View (Helley and others, 1972) quadrangles the unit contains a finegrained fossiliferous stratum at its base. Fauna and flora from this stratum are about 20,000 years old and are representative of a cooler climate. This fossiliferous stratum was not seen in this map area.

\section{HOLOCENE DEPOSITS}

Holocene deposits in the map area are widely distributed on the flatlands and also are present locally in areas of high relief and along the coast. Urban developments on the gently sloping flatlands have modified or obscured these deposits, but studies of old topographic maps and data from wells drilled for water or engineering purposes enabled Helley and Lajoie (1979) to identify and classify the deposits and have provided some 
of the information shown on this map. The historic landward extent of bay mud $(\mathrm{Om})$, little of which remains exposed, is based on personal observation and U.S. Coast Survey $(1853 \mathrm{a}, \mathrm{b} ; 1854 ; 1857 \mathrm{a}, \mathrm{b} ; 1868)$ topographic maps of the margins of the San Francisco Peninsula. Watersaturated deposits of bay mud are considered to be highly susceptible to liquefaction during earthquakes (Youd and Perkins, 1987) and during the October 19, 1989, Loma Prieta event, sand boils-evidence of liquefaction-formed along the bay margin $1.3 \mathrm{mi}$ west of Little Coyote Point (R.D. Brown, Jr., oral commun., 1989). No similar effects were reported elsewhere in the map area.

Deposits created by various types of landslides are classified as older (unit Qol) and younger (unit Qyl) on the basis of activity, the older ones showing no evidence of movement in the past several decades (for example, distress of older man-made structures). Within the map area the distribution of older and younger landslide deposits shows that sheared rock (unit $\mathrm{fsr}$ ), slope wash, ravine fill, and colluvium (unit Qsr), and weathered granitic rock are especially susceptible to slope failure (Brabb and Pampeyan, 1972; Brabb and others, 1972; Ellen and Wieczorek, 1988). In addition, slopes underlain by the Purisima Formation (unit $T p$ ) and upper part of the Paleocene sandstone, shale, and conglomerate (unit Tsu) are prone to failure where oversteepened by wave action or faulting. The large landslides at Seal Cove were studied by Leighton and Associates (1971) and those north of Devils Slide by Beeston and Gamble (1980). Many large slides have occurred along Pilarcitos and San Mateo Creeks where canyons cut in fault zones have steep, northeastfacing, colluvium-covered walls and the soil-moisture content remains relatively high. Numerous shallow debris flows on Montara Mountain, occurring during or following prolonged periods of precipitation, have little economic consequence, but in some areas, for example north of San Pedro Valley, shallow debris flows in colluvium triggered by heavy rains in January of 1982 (Howard and others, 1988) caused deaths and significant property damage. For an analysis of slope stability in the map area under normal and seismic loading conditions, see Brabb and others (1972) and Wieczorek and others (1985).

Beach deposits (unit $\mathrm{Ob}$ ) are present along the coast and at a few places along the bay margin. The deposits along the coast are clean siliceous sands derived mainly from granitic rock of Montara Mountain, whereas the deposits along the bay are dirty sands derived locally from reworked artifical fill materials. Construction of a breakwater in 1959-61 to protect Pillar Point Harbor has disturbed the transport of sand by longshore currents causing accretion of beach deposits within the breakwater and erosion of beach and terrace deposits outside the breakwater (Tinsley, 1972). At Laguna Salada and at Pacifica beach northeast of Shelter Cove, dunes composed of windblown beach sand are present along the back edge of the beaches. Other areas of dune sand and beach deposits along the coast are too small to show at map scale.

A mantle of debris referred to as slope wash, ravine fill, and colluvium (unit Qsr), derived from underlying weathered bedrock units, is present throughout most of the map area. It was mapped where believed to exceed $5 \mathrm{ft}$ in thickness. It is thickest west of the San Andreas Fault Zone on Franciscan rocks and east of the fault zone on Franciscan rocks in San Mateo, thinning to zero northwest and southeast. The distribution of this unit may be related to slope orientation, slope angle, and vegetative cover as the mantle appears to be thickest under dense tree and brush cover on moderate to steep slopes in rural and undeveloped areas. The distribution of small and large landslides show that this unit is susceptible to slope failure, especially when water-saturated (Bonilla, 1960).

Artificial fill in the map area consists of various natural and man-made materials emplaced by a variety of methods, and where recognizable was mapped as unit $\mathrm{Qf}_{1}$. In the mid-1940's at least some of the fill used in the construction of San Francisco International Airport was trucked from quarries in the Franciscan Complex and Merced Formation at the west end of Helen Drive in Millbrae, and in the late 1960's and early 1970's hydraulically-placed fill dredged from adjacent marsh lands and sloughs was placed on Brewer Island and vicinity, the site of Foster City. Some of the oldest fills are along or near the historic bay margin as levees to create salt evaporation ponds, and some of the youngest are sanitary landfills. Natural phenomena, residential, commercial, and highway construction continue apace to alter the original topography of the area so the extent of artificial fill shown represents only a brief moment in time. Early maps (U.S. Coast Survey, 1853a, 1869) show that as late as 1869 the mouth of San Pedro Valley contained a lagoon on the submerged Mussel RockHalf Moon Bay terrace. By 1892 (U.S. Geological Survey, 1899) the lagoon was replaced by two lakes, the largest named Lake Mathilde, which by 1914 (U.S. Geological Survey, 1915) had disappeared, probably by natural filling with beach and dune deposits, and subsequently this area reached its present state by the use of imported artificial fill. Similarly Laguna Salada must have had access to the sea and was a natural salt evaporating pond where early dwellers came to gather salt. Most of the modern fills are engineered while many of the old fills were random mixtures of rock, soil, and waste materials. Pilarcitos (1864-66), San Andreas (1868-70), and Upper Crystal Springs (1875-77) dams are early examples of engineered, clay puddle-core, embankments that withstood the 1906 San Francisco earthquake, the latter two dams being in the San Andreas Fault Zone. Clay for the core of Pilarcitos dam came from the floor of Pilarcitos valley, probably from older alluvium (Hay, 1927, p. 121-122); clay for the core of San Andreas dam probably came from similar deposits in San Andreas valley.

In parts of Burlingame, Millbrae, San Bruno, and the Linda Mar district of Pacifica a comparison of 1949 and 1956 editions of the Montara Mountain topographic quadrangle showed areas (not readily discernable during field mapping) where rugged topography had been smoothed out. These areas, shown as unit $\mathrm{Of}_{2}$, are believed to have been filled during grading operations. In addition there are parts of Linda Mar developed after 1956 where the slopes have been steepened by grading; in 
these areas the geology was mapped on post-1968 aerial photographs and projected onto the pre-existing topography.

Younger alluvium (unit Oya) was mapped in a few drainages where modern runoff carries and moves rock debris. Some of the areas of coarse-grained alluvium (unit $\mathrm{Qac}$ ) and slope wash, ravine fill, and colluvium (unit Osr) include strips of younger alluvium too narrow to show. Most of the drainage channels in urbanized areas have been lined or enclosed thereby eliminating the accumulation of much of younger alluvium.

Two areas on the map are designated as undivided sedimentary deposits (unit OTs). These areas may include various Tertiary to Holocene units, but grading, landscaping, and lack of access or urban development precluded assigment of the earth materials to a specific map unit. The smaller area is the site of the Green Hills Country Club and probably is underlain by the Merced and Colma Formations and coarse-grained alluvium. The larger area probably consists mostly of older alluvium and colluvium but may contain some Colma deposits and unnamed Tertiary and Quaternary coarse clastic deposits (Lajoie and others, 1974).

The methods of study, characteristics and interrelations of the Pleistocene and Holocene deposits, and their importance to comprehensive planning are discussed in detail in Helley and others (1979). Atwater and others (1977) describe the late Quaternary history of San Francisco Bay.

\section{STRUCTURE}

The map area is cut by three major faults, the Pilarcitos, San Andreas, and Seal Cove (fig. 1), and the Pilarcitos Fault marks the boundary betweer, two different types of basement rocks, the Franciscan Complex on the east and granitic rock on the west. The named faults typically are zones of faulting ranging in width from a few feet to $500 \mathrm{ft}$ or more. The lines shown on the map represent the most prominent-and most recently activetraces of faults in the respective zones.

The trace of the Pilarcitos Fault, from its point of divergence with the San Andreas Fault near the San MateoSanta Cruz County boundary to the head of San Pedro Valley at Whiting Ridge, is not deflected as it crosses ridges and ravines indicating a vertical or very steeply dipping fault plane not unlike the vertically dipping zone of sheared Paleocene rocks exposed in the east abutment of the Pilarcitos dam. The remainder of the fault onshore, in part confined to a narrow linear ravine, is concealed by Quaternary deposits in San Pedro Valley; offshore the fault continues northwest and merges with the San Gregorio Fault which in turn joins the San Andreas Fault off the Golden Gate (McCulloch, 1989, fig. 12).

Lawson (1895, p. 437) first recognized a significant fault in Pilarcitos canyon along which granitic rocks on the southwest side were thrust up against Franciscan rocks, and he extended the fault to the coast between Spring Valley and Fifield Ridges to the mouth of Calera Valley (Lawson, 1908, pl. 15). Branner and others (1909) extended the fault $18 \mathrm{mi}$ southeast of the map area as a vertical west-side-down fault. Subsequently Lawson (1914) described the Pilarcitos Fault as a northeast-dipping highangle reverse fault, a view shared by Darrow (1963). Wakabayshi and Moores (1988) believe the Pilarcitos Fault extends only from near Highway 92 northwest to the coast as a northeast-dipping thrust-part of a suture between subducted granitic basement rocks and overthrust Franciscan rocks, and that south of Highway 92 several high-angle faults are overprinted and obscure the thrust. Smith's (1960) analysis of geomorphic evidence indicates that the Pilarcitos Fault is a right-lateral strike-slip fault intermittently active until late Pleistocene time. Dibblee's (1966a) comparison of Tertiary formations along the Pilarcitos and San Andreas Faults indicates that the Pilarcitos and San Francisco Bay blocks moved as a unit, "...the main shift being along the Pilarcitos Fault prior to deposition of the Purisima Formation, and then along the San Andreas Fault since that time". In summary, the evidence strongly indicates the Pilarcitos Fault is an ancestral trace of the San Andreas Fault with about $20 \mathrm{mi}$ of right slip (Dibblee, 1966b); the fault probably also has a vertical component of slip with the northeast side up, possibly a counterpart of the Serra Fault and other branching reverse faults along the northeast side of the San Andreas Fault. The Pilarcitos Fault is not considered to be potentially active (California Division of Mines and Geology, 1982) but may be seismically active on the basis of clusters of seismic activity near Portola Valley, $10 \mathrm{mi}$ southeast of the map area, and near Montara Mountain (Brabb and Olson, 1986).

The San Andreas Fault cuts diagonally through the map area entirely in watershed lands of the City of San Francisco. The fault was formally named by Lawson (1908, p. 2) after the San Andreas valley west of Millbrae, though he previously mentioned the "...San Andreas Fault..." (Lawson, 1895, p. 441) after commenting on "...a remarkably straight fault which has conditioned the San Andreas and Spring Valley, one of the most noteworthy features of the topography." (Lawson, 1895, p. 439). The San Andreas Fault is the boundary between the Pacific and North American crustal plates which are sliding past each other at a rate of about 1.38 to 1.97 in. (35 to $50 \mathrm{~mm}$ ) per year (Argus and Gordon, 1990). Throughout much of California this boundary separates granitic basement rocks from Franciscan basement rocks, the Salinian and Northern Franciscan areas of Reed (1933), but in this area, as noted above, the Pilarcitos Fault forms the basement boundary.

In this area the San Andreas Fault is a zone of faulting with a maximum width of about $500 \mathrm{ft}$. Within the zone only the most recently active traces are shown, those thought to mark the 1906 surface rupture (Pampeyan, 1983). Several large historic earthquakes have occurred on this fault, the most notable in northern California being the April 18, 1906, M 8.2 San Francisco earthquake whose epicenter is generally located offshore between Mussel Rock and Bolinas Bay (about 12 mi northwest of the map area). Within the map area fences, pipelines, roads, and other manmade structures were offset as much as $11 \mathrm{ft}$ in that event (Schussler, 1906; Lawson, 1908; Pampeyan, 1983), and possibly more. The historical 
records for earlier earthquakes in this area are less accurate and leave room for speculation on location of epicenter, magnitude, exact date, and length of surface rupture for major events. In 1906 the surface rupture resembled one or more plowed furrows-except that the sod was not turned over-some in straight lines and others in en echelon patterns (Lawson, 1908, pl. 61). The movement was mainly right-lateral strike-slip, but small components of vertical displacement were reported in a few places (Lawrence, 1924; Pampeyan, 1983, 1986). Within the map area much of the 1906 surface rupture was under water, but a fault plane was exposed at one locality believed to be near the northwest end of Lower Crystal Springs Lake (Lawson, 1908, pl. 62A; Pampeyan, 1983); otherwise the 1906 surface rupture zone has been exposed only during drought years of 1924 and 1931 or on rare occasions when lake levels were lowered for construction purposes (Pampeyan, 1975, 1983). Branching and secondary faults also were reported in 1906, for example near Crystal Springs Dam "...cracks emerged from the lake and ran northward up on the hills for several hundred yards, breaking fences where they crost." (Lawson, 1908, p. 93), and between San Andreas Lake and Mussel Rock to the north "...there were, in general, furrows on either side of the main fault, at various distances up to 200 feet. Some of these were persistent for considerable distances." (Lawson, 1908, p. 95).

Following the 1906 earthquake the State Earthquake Investigation Commission established a quadrilateral of monuments across the fault rupture, about $2 \mathrm{mi}$ northwest of Crystal Springs Dam (Lawson, 1908, p. 156), for the purpose of making exact measurements of any future movements. The quadrilateral was resurveyed in 1947, 1957, and 1963 and according to Parkin (1965, p. 5) the changes were "...practically negligible." and did not establish a trend. In 1973 I found the northwest and southwest monuments still in place, the northeast monument had been disturbed during construction of a pipeline, and I did not find the southeast monument. Measurements of displacement across the most recently active strand of the San Andreas Fault in Woodside, about $3.5 \mathrm{mi}$ southeast of the map area, demonstrate horizontal deformation at varying rates which average out to a tectonic slip rate of $0.09 \mathrm{in}$. $(2.2 \mathrm{~mm}) / \mathrm{yr}$ (Harsh, 1977). Longterm geodimeter measurements across the map area show no aseismic slip but about 0.4 in. $(10 \mathrm{~mm}) / \mathrm{yr}$ of strain build-up across the San Andreas Fault Zone (Bennett, $1980)$, suggesting the total plate motion is distributed over a wider zone of coastal California. The San Andreas Fault is tectonically active and is zoned for Special Studies (California Division of Mines and Geology, 1974, 1982).

The Seal Cove Fault is a part of the San GregorioHosgri Fault Zone, a mostly offshore zone of faulting extending about $270 \mathrm{mi}$ from the vicinity of Bolinas Bay south to near Point Sal (Graham and Dickinson, 1978; McCulloch, 1989). The onshore parts of this zone have been mapped in segments by Weber and Lajoie (1980) who described geomorphic evidence for recency of movements on each segment. One of these segments, the Seal Cove Fault, lies at the base of a east-facing scarp along the west edge of the Half Moon Bay Airport. The Seal Cove bluffs are an upthrown block between the Seal
Cove segment and the main part of the San Gregorio Fault lying a few miles offshore and parallel to the Seal Cove Fault (McCulloch, 1989). At Moss Beach an excellent sea-cliff exposure of the Seal Cove Fault showing 80,000 to 85,000-yr-old marine terrace deposits against lower Pliocene Purisima mudstone was covered with riprap in the 1980's to retard erosion of the cliff. Numerous faults and lineaments parallel to the Seal Cove Fault are visible in the sea cliff near Moss Beach, in the wave-cut bench along the Seal Cove bluffs, and in marine terrace deposits west and north of Half Moon Bay airport. The Seal Cove bluffs themselves are cut by faults, one of which juxtaposes the Purisima Formation and granitic rock under a cover of terrace deposits (Leighton and Assoc., 1971). Some of these faults coincide with lineaments visible on aerial photographs, the youngest and most significant example, referred to here as the Denniston Creek Fault, cuts Holocene alluvium (Lajoie and others, 1972; Weber and Lajoie, 1980). All of these faults and lineaments are presumed to be in the San Gregorio-Hosgri Fault Zone. The amount of right slip on the Seal Cove Fault is not known but Glen's (1959) correlation of Pliocene rocks in the Seal Cove bluffs with the type Purisima Formation at Purisima Creek, about $9 \mathrm{mi}$ south of the map area, suggests at least $9 \mathrm{mi}$ of lateral offset; the vertical component of slip on the Seal Cove Fault is at least 148 $\mathrm{ft}$ adjacent to the Half Moon Bay Airport on the basis of offset terrace deposits (Kennedy and others, 1982). The Seal Cove and Denniston Creek Faults are considered to be potentially active and have been zoned accordingly for Special Studies (California Division of Mines and Geology, 1982). Theodolite measurements across the Seal Cove Fault at a site west of Princeton showed left slip of 0.156 in. between November 1979 and February 1980 and then right slip of 0.256 in. between February 1980 and April 1981, but these data did not show a trend (Galehouse, 1981).

A zone of southwest-dipping reverse faults named the Serra Fault Zone is east of and subparallel to the San Andreas Fault from San Bruno to Hillsborough. Faulting in this zone was first noted in 1955 in the Montara Mountain quadrangle by M.G. Bonilla and about 1957 named on his geologic map of the San Francisco South quadrangle (1965, 1971a). In 1955 M.G. Bonilla and C.R. Appledorn examined and photographed an artificial exposure about $1 / 2$ mi east of Crestmoor High School, at the east edge of the present North Park. They determined that one of the shallow west-dipping faults exposed there displaced beds of the Merced Formation, "old alluvium", and modern soil (M.G. Bonilla, written commun., 1992). Smith (1960, fig. 75) photographed a few strands of the fault, which were exposed during grading operations in west Millbrae, and plotted their positions on his map. This zone of faulting approximately coincides with part of the Foothill Thrust, a line drawn along the east base of the Santa Cruz Mountains by Willis (1938, fig. 1). Apparently Willis believed the mountainflatland boundary should be a reverse fault but he presented no evidence to accompany his sketch map. A similar line labelled as the Belmont Fault-possibly based on Willis' Foothill Thrust-was shown by G.F. Engle in a memorandum report on the Crystal Springs Dam made 
for the San Francisco Water Department in 1930. Engle's Fault extends northwest from Laurel Creek, $0.6 \mathrm{mi}$ southwest of Hillsdale High School, through the intersection of highway I-280 and the north edge of this map in nearly a straight line as far north as the Chinese Cemetery in Colma (about $19 \mathrm{mi}$ ). In places this line coincides with mapped traces in the Serra Fault zone. At the north edge of the map one strand of the Serra Fault dips $20^{\circ}$. $40^{\circ}$ west and places Franciscan sheared rock (unit fsr) on the Colma Formation. Elsewhere to the southeast imbricated strands juxtapose Franciscan and Merced rocks in a zone at least $3,000 \mathrm{ft}$ wide. The zone of faulting may be wider and extend farther southeast than shown along both the Merced-Colma contact and (possibly) the Franciscan Complex-Holocene deposits contact. The Serra Fault is not known to be seismically active and has not been zoned for Special Studies (California Division of Mines and Geology, 1982).

In Belmont and San Carlos a steeply dipping to vertical, northwest-striking fault cuts through the hills and passes under alluvium at either end. This fault referred to as the Belmont Hill Fault (Pampeyan, 1981b), is in Franciscan chert and graywacke, both of which have been locally altered to clay minerals along the fault. On Belmont Hill some small landslides are in clay-rich rock and soil on oversteepened slopes along the fault. The Belmont Hill Fault probably passes east of an outlier of chert on the west side of El Camino Real near Hillsdale Boulevard and may extend through or just east of another outlier of chert and graywacke in central San Mateo. Half a mile east of the Belmont Hill Fault, a fault referred to as the Angelo Fault cuts Franciscan conglomerate, graywacke, and greenstone, the latter being altered to clay minerals near the fault. The fault is named for U.S. Coast Survey (1853b) triangulation station ANGELO which at one time occupied the summit of a small hill at this site. The strikes of the Belmont Hill Fault, Angelo Fault, and an unnamed fault in the basement-rock outlier in central San Mateo are parallel and project northwestward toward a subsurface projection of the San Bruno Fault (Lawson, 1914; Bonilla, 1971a). The existence of a fault or fault zone under the flatlands is suggested by a trough of Pliocene(?) to Holocene deposits between basement highs at Coyote Point, Little Coyote Point, and central San Mateo. Water-well logs show an apparent step down of basement between these basement highs in a trend that extends southeast towards Redwood City (Hensolt and Brabb, 1990).

Other prominent faults or zones of faulting in the map area are recognized but little is known of them because of their inactivity, inaccessibility, and(or) lack of exposure. The San Mateo Fault, west of the San Andreas Fault, follows a structurally controlled drainage but little more is known about it. The north arm of Pilarcitos Lake also is in a fault-controlled ravine, and the northwest-striking serpentinite bodies on Fifield Ridge follow a fault which in part separates greenstone and graywacke from sheared rock (unit fsr). As noted above, faults cutting the sheared rock unit locally consist of narrow steep zones of shearing or gouge in rocks showing flat-lying or gently dipping shear foliation.
Darrow (1963) and Morgan (1981a) each mapped faults along part of the boundary separating granitic and sedimentary rocks on San Pedro Mountain. This boundary, here referred to as the San Pedro Mountain Fault, extends southeast from Devils Slide (Beeston and Gamble, 1980) to Pilarcitos Lake and beyond to join the Pilarcitos Fault. Over most of its length the fault is poorly exposed, but where exposed it is marked by a narrow sheared and brecciated zone dipping $40^{\circ}-60^{\circ}$ north. At its northwest end, in roadcut and seacliff exposures north of Devils Slide, the main fault strand dips gently north under massive slope failures in Paleocene sedimentary rocks; near its southeast end the fault is poorly exposed but appears to branch before merging with the Pilarcitos Fault.

Additional information on the major faults and seismicity in San Mateo County can be found in Brabb and Olson (1986) and Wesson and others (1975).

Compressional deformation resulting from ongoing tectonic activity and strain build-up in this part of the Santa Cruz Mountains is evidenced by folding in deposits as young as late Pleistocene. In the Pigeon Point and La Honda blocks the youngest emergent marine terrace deposits $(80,000-85,000 \mathrm{yr}$ B.P.) and the underlying Half Moon Bay-Mussel Rock terrace are gently warped. According to Lajoie and others (1972) the Half Moon Bay terrace gradually drops in elevation from about 20 $\mathrm{ft}$ above sea level near Point Montara to $60 \mathrm{ft}$ below sea level south of Half Moon Bay Airport and rises to 140 $\mathrm{ft}$ above sea level $10 \mathrm{mi}$ south of $\mathrm{El} \mathrm{Granada.} \mathrm{The} \mathrm{equivalent}$ Mussel Rock terrace also is warped and falls from over $200 \mathrm{ft}$ above sea level $2 \mathrm{mi}$ north of the map area to below sea level at Laguna Salada (Schlocker and Bonilla, 1962; Bonilla and Schlocker, 1966). Calera and San Pedro Valleys are drowned parts of this terrace. Moderate folding in the lower Pliocene Purisima Formation is well exposed in the wave-cut bench between Moss Beach and the south edge of the map, for example, the Moss Beach Syncline and the Whalemen's Harbor Anticline. Lawson $(1914$, p. 16) speculated that these beds, which rest nonconformably on granitic rocks, were "...crowded horizontally..." and folded without deforming the underlying erosional surface. The Paleocene rocks at Devils Slide have undergone even more compressional deformation and are isoclinally folded and locally overturned. Smith (1960, p. 130-135) found no evidence to indicate warping of his Colma sequence of terraces, but moderately dipping upper Pliocene Merced strata and gently dipping Pleistocene Colma strata suggest deformation may be proceeding at a similar rate in the San Francisco Bay block.

Franciscan rocks in the San Francisco Bay block are folded, but no areal or regional trend was obvious except perhaps for an apparent eastward dip of the sheared rockgraywacke contact between San Mateo and San Carlos. In the Pilarcitos block Lawson (1914) showed the main northwest-trending ridges as open synclines, separated by faults, with greenstone or limestone in their cores. That may be an accurate representation of the overall structural setting, but in places, for example on Cahill Ridge, I found no clues as to how the outcrops on the southwest side of the ridge were related to outcrops along 
Lower Crystal Springs Reservoir on the northeast side of the ridge.

The geomorphology of the map area has been discussed by Lawson $(1895,1914)$ and Smith (1960), as parts of studies covering larger parts of the San Francisco Bay region. Large-scale urbanization of the map area beginning in the 1950's has changed much of the land surface so some of the critical geomorphic evidence no longer exists or is not easily decipherable.

\section{GEOPHYSICAL STUDIES}

An aeromagnetic study of the San Francisco Bay region shows three linear positive anomalies in the map area that are interpreted to represent steeply dipping tabular bodies of serpentinite in zones of crustal weakness (Brabb and Hanna, 1981). These positive anomalies are named (1) San Pedro anomaly, (2) Pulgas Ridge anomaly, and (3) Redwood City anomaly (fig. 4). The San Pedro anomaly extends across the map area from the south end of Cahill Ridge northwest to Rockaway Beach and beyond, subparallel to but just northeast of the Pilarcitos fault. North of San Pedro Valley this anomaly appears to follow the contact between sheared Franciscan rock (unit fsr) and relatively unbroken bodies of greenstone and graywacke. The Pulgas Ridge anomaly trends northwest along Pulgas and Buri Buri Ridges, possibly in response to a steeply dipping serpentinite source from which the exposed gently dipping serpentinite sheet originated. The northwest end of the Redwood City anomaly (the Redwood City Fault Zone of Brabb and others [1990]) is east of Coyote Point. Figure 4 shows the Redwood City anomaly is divided into north and south branches, interpreted to reflect the presence of a faulted or folded sheet of serpentinite at depth. The two branches of the Redwood City anomaly merge and extend southeast across the adjacent Redwood Point and Palo Alto quadrangles (Brabb and others 1990; Pampeyan, 1993). No magnetic anomalies were noted along the San Andreas Fault in the map area. A broad negative anomaly centered over Montara Mountain is believed to indicate reversed magnetic polarity of the granitic pluton (Brabb and Hanna, 1981).

Gravity studies in the San Francisco Bay region (Chapman and Bishop, 1968; Robbins and others, 1982) show the map area to be dominated by a positive anomaly centered on the granitic rock of Montara Mountain and adjacent dense Franciscan rocks. This anomaly is elongate subparallel to the San Andreas Fault and slopes northeast to a low along the east edge of San Francisco Bay. The positive anomaly crosses both the Pilarcitos and San Andreas Faults obliquely without any distinctive breaks to mark these faults.

\section{MINERAL RESOURCES}

To date no economic deposits of metallic minerals have been found in the map area, and the non-metallic mineral commodities produced in the map area consist chiefly of rock products. One exception is salt $(\mathrm{NaCl})$ gathered by early dwellers of the region at Laguna Salada, which at one time was a natural evaporation pond on the "drowned" Mussel Rock marine terrace. Around the turn of the century evaporation ponds were created in the vicinity of Belmont Slough by building levees on the marshlands. These ponds were used in the salt-making process for about 60 years before production here was phased out and moved to the east edge of the bay. According to Ver Planck (1958) a Leslie Salt Refining Company was in operation in San Mateo in 1901, before the main operations began in Redwood City in 1908. In the 1960's many of the older evaporation ponds were filled and converted to residential and other commercial uses.

Another nonmetallic non-rock commodity of the map area was oyster (Ostrea lurida) shells dredged from the bay for use in making Portland cement. In 1924 the Pacific Portland Cement company began an operation in Redwood City (Bowen, 1957), which continued until the plant became uneconomic to maintain in the 1970's. The oyster shells provided lime and the accompanying clayey sediment provided alumina, silica, and iron oxide for the process (Bowen and Gray, 1962a, b).

Rock units of the Franciscan Complex have been used in various ways. During construction of Crystal Springs concrete arch dam (1887-1890), graywacke, hand-quarried from a tectonic inclusion $0.6 \mathrm{mi}$ northwest of the dam site, was used as aggregate in the dam (Watts, 1888; Spring Valley Water Works, Photo Album, 1866-1904, photo no. 83 , p. 34 and photo on. p. 38 , both photos c. 1887, San Francisco Public Utilities Commission photos X-7842 (D-1244) and M-1755, respectively). Conglomerate, greenstone, and chert were quarried for use as fill from a hill locally known as Quarry Hill, the former site of U.S. Coast Survey triangulation station ANGELO in Belmont, and chert from small quarries along on the west side of I-280 has been used for road metal in San Francisco watershed lands. Sheared rock (unit fsr) and sandstone from the Merced Formation was quarried in Millbrae in the late 1940's and early 1950's between the present west end of Helen Drive and I-280 for use as fill to extend the runways of San Francisco airport, prior to residential development of western Millbrae. The Calera Limestone was quarried in and near Rockaway Beach and on Cahill Ridge for use as rip rap, road metal, concrete aggregate, and in sugar refining. Hay (1927) reported that blue clay from Pilarcitos canyon was used for the impervious core of Pilarcitos dam. Clay from an unknown-but presumably local-source also was used for the "puddle core" of San Andreas Lake dam in 18681869 (Pampeyan, 1983). Serpentinite slopes in the east abutment of San Andreas Lake dam are scarred and may have been a source for some of the embankment material; a nearby quarry (in sandstone) postdates construction of the dam. Specific sites for major sources of embankment material for the Pilarcitos Lake (1984-66), Upper Crystal Springs Reservoir (1975-77), and San Andreas Lake (1868-69) dams are unknown but must have been close to the construction sites; embankment material for the Pilarcitos dam may also have included granitic rock and Paleocene sedimentary rocks.

Tne granitic rock of Montara Mountain (unit $\mathrm{Km}$ ), in the form of "decomposed granite" from several small quarries between El Granada and the vicinity of Montara 
Beach, has been used for fill and base rock in road construction. Fresh granitic rock is quarried in Nuff Creek, just south of the map area, for various uses where only minus 1-1/2-in- size material is needed. In open-cut exposures more than $50 \mathrm{ft}$ deep, pervasive fracturing allows the fresh rock to be ripped and loaded without crushing, and only rarely is blasting required.
Surficial unconsolidated deposits-including bay mud, along with bedrock units, have been widely used for artificial fill, especially along the edge of San Francisco Bay where a historic network of sloughs and intervening marshland have been covered and developed for residential and commercial uses.
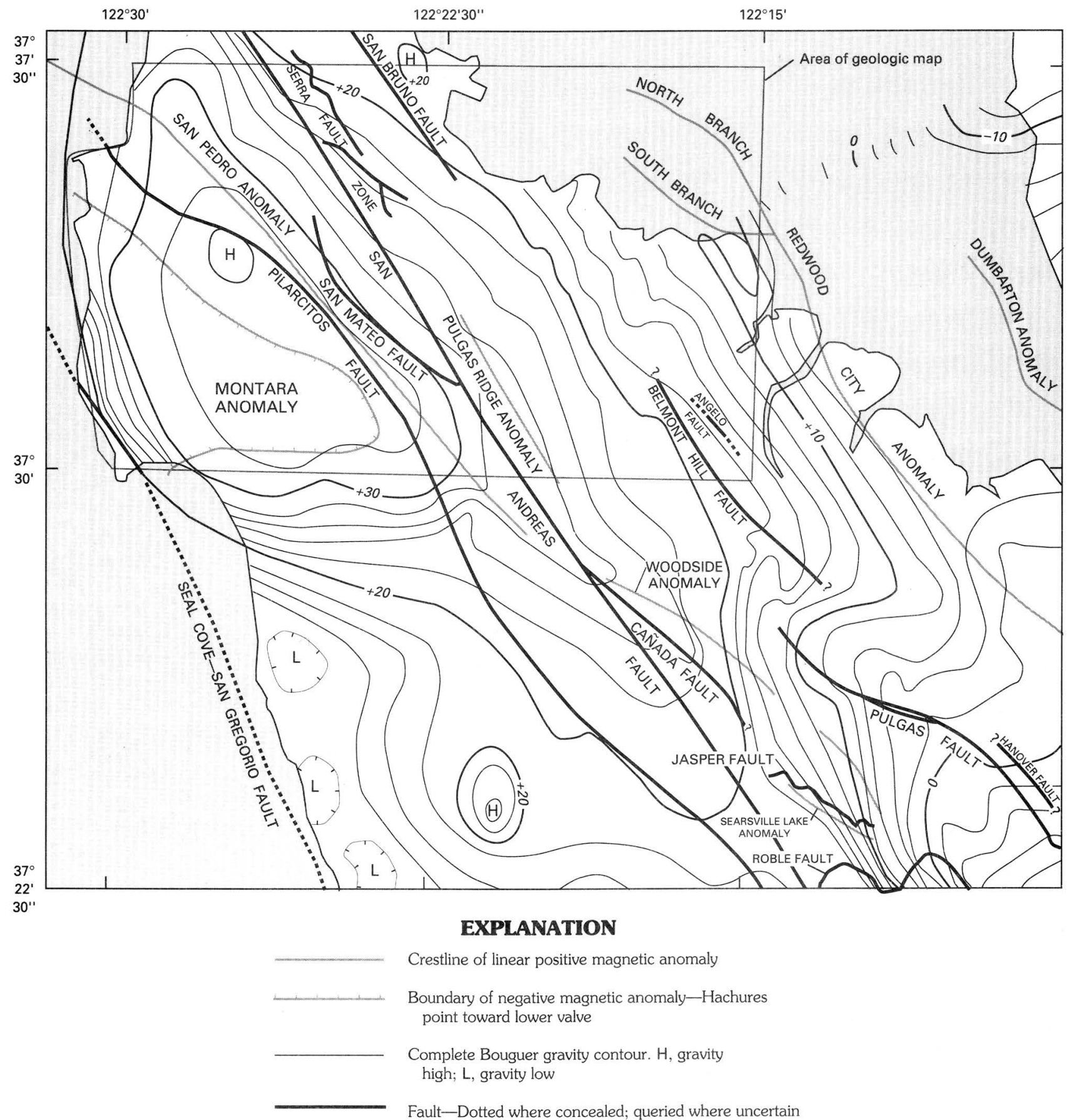

Figure 4. Complete Bouguer gravity contours, aeromagnetic anomalies, and principal faults in the study area and vicinity. Gravity data from Robbins and others (1982); contour interval 2 mGals. Aeromagnetic data from Brabb and Hanna (1981) and V.E. Langenheim and R.F. Sikora (unpub. data, 1991). 


\section{REFERENCES CITED}

Adam, D.P., McLaughlin, R.J., Sorg, D.H., Adams, D.B., Forester, R.M., and Repenning, C.A., 1983, An animal- and plant-fossil assemblage from the Santa Clara Formation (Pliocene and Pleistocene), Saratoga, California, in Anderson, D.W., and Rymer, M.J., eds., Tectonics and sedimentation along faults of the San Andreas system: Los Angeles, Society of Economic Paleontologists and Mineralogists, Pacific Section, p. 105-110.

Addicott, W.O., 1969, Late Pliocene mollusks from northwest Santa Clara County, California, and their paleogeographic significance: Proceedings, California Academy of Sciences 4th Series, v. 37, no. 3, p. 57-93.

Alvarez, Walter, Kent, D.V., Premoli Silva, I., Schweikert, R.A., and Larson, R.A., 1980, Franciscan Complex limestone deposited at $17^{\circ}$ south paleolatitude: Geological Society of America Bulletin, v. 91, no. 8, pt. I, p. 476-484.

Argus, D.F., and Gordon, R.G., 1990, Pacific-North American Plate motion from very long baseline interferometry compared with motion inferred from magnetic anomalies, transform faults, and earthquake slip vectors: Journal of Geophysical Research, v. 95 , no. B11, p. 17,315-17,324.

Atwater, B.F., Hedel, C.W., and Helley, E.J., 1977, Late Quaternary depositional history, Holocene sealevel changes, and vertical crustal movement, southern San Francisco Bay, California: U.S. Geological Survey Professional Paper 1014, 15 p.

Bailey, E.H., Irwin, W.P., and Jones, D.L., 1964, Franciscan and related rocks, and their significance in the geology of western California: California $\mathrm{Di}$ vision of Mines and Geology Bulletin 183, $177 \mathrm{p}$.

Beaulieu, J.D., 1970, Cenozoic stratigraphy of the Santa Cruz Mountains, California, and inferred displacement along the San Andreas Fault: Stanford, California, Stanford University, Ph.D. thesis, 202 p.

1971, Cenozoic stratigraphy of the Santa Cruz Mountains, and inferred displacement along the San Andreas Fault [abs.]: Dissertation Abstracts International, Part B, Science and Engineering, v. 32, no. 2, p. 1019-B.

Bechtel Corporation, 1966, Geologic study of the Crystal Springs Bypass Tunnel project area: Unpublished report prepared for the San Francisco Public Utilities Commission, map sheets 3-7, scale 1:9600.

Beeston, H.W., and Gamble, J.H., 1980, Engineering geology of the Devil's Slide at San Pedro Mountain, San Mateo County, California: California Transportation Laboratory, Report 04-SM-1, 56 p.

Bennett, J.H., 1980, Geodimeter measurements of strain and slip along the northern San Andreas Fault system, in Streitz, Robert, and Sherburne, Roger, eds., Studies of the San Andreas Fault zone in northern California: California Division of Mines and Geology Special Report 140, p. 99-109.
Bonilla, M.G., 1960, Landslides in the San Francisco South quadrangle, California: U.S. Geological Survey Open-File Report, $44 \mathrm{p}$.

1965, Geologic map of the San Francisco South quadrangle, California: U.S. Geological Survey OpenFile Map 65-18, scale 1:20,000.

1971a, Preliminary geologic map of the San Francisco South and part of the Hunters Point quadrangle, California: U.S. Geological Survey Miscellaneous Field Studies Map MF-311, scale 1:24,000.

1971b, Bedrock-surface map of the San Francisco South quadrangle, California: U.S. Geological Survey Miscellaneous Field Studies Map MF-334, scale $1: 31,680$.

Bonilla, M.G., and Schlocker, Julius, 1966, Field trip, San Francisco Peninsula, in Bailey, E.H., ed., Geology of northern California: California Division of Mines and Geology Bulletin 190, p. 441-452.

Bowen, O.E., Jr., 1957, Cement, in Wright, L.A., ed., Mineral commodities of California: California $\mathrm{Di}$ vision of Mines Bulletin 176, p. 113-120.

Bowen, O.E., and Gray, C.H., Jr., 1962a, The Portland cement industry in California, 1962-Part I: California Division of Mines and Geology, Mineral Information Service, v. 15, no. 7, p. 1-7. 1962b, The Portland cement industry in California, 1962-Part II: California Division of Mines and Geology, Mineral Information Service, v. 15, no. 8, p. 1-11.

Brabb, E.E., 1983, map showing direction and amount of bedding dip of sedimentary rocks in San Mateo County: U.S. Geological Survey Miscellaneous Investigations Series Map I-1257-C, scale 1:62,500.

Brabb, E.E., and Hanna, W.F., 1981, Maps showing aeromagnetic anomalies, faults, earthquake epicenters, and igneous rocks in the southern San Francisco Bay region: U.S. Geological Survey Geophysical Map GP-932, scale 1:125,000.

Brabb, E.E., and Olson, J.A., 1986, Map showing faults and earthquake epicenters in San Mateo County, California: U.S. Geological Survey Miscellaneous Investigation Series Map I-1257-F, scale 1:62,500.

Brabb, E.E., and Pampeyan, E.H., 1972, Preliminary map of landslide deposits in San Mateo County, California: U.S. Geological Survey Miscellaneous Field Studies Map MF-344, scale 1:62,500. 1983, Geologic map of San Mateo County, California: U.S. Geological Survey Miscellaneous Investigations Series Map I-1257-A, scale 1:62,500.

Brabb, E.E., Carle, S.F., and Pampeyan, E.H., 1990, Map showing elevation of bedrock surface beneath the flatlands of Menlo Park, Atherton, and adjoining areas, California, in Oliver, H.W., ed., 1990, Preliminary ground water quality data and the extent of the ground water basin from drill hole, gravity, and seismic data in the Palo Alto 7.5-minute quadrangle, California: U.S. Geological Survey OpenFile Report 90-74, pl. 1, scale 1:24,000. 
Brabb, E.E., Pampeyan, E.H., and Bonilla, M.G., 1972, Landslide susceptibility in San Mateo county, California: U.S. Geological Survey Miscellaneous Field Studies Map MF-360, scale 1:62,500.

Brabb, E.E., Taylor, F.A., and Miller, G.P., 1982, Geologic, scenic, and historic points of interest in San Mateo County, California: U.S. Geological Survey Miscellaneous Investigations Series Map I-1257-B, scale 1:62,500.

Branner, J.C., Newsom, J.F., and Arnold, Ralph, 1909, Description of the Santa Cruz quadrangle [California]: U.S. Geological Survey Geologic Atlas, Folio 163, 11 p., 3 map sheets, scale 1:125,000.

California Division of Mines and Geology, 1965, Potassium-argon age dates for some California localities: California Division of Mines and Geology, Mineral Information Service, v. 18, no. 1, p. 16.

1974, Special Studies Zones, San Mateo quadrangle: California Division of Mines and Geology, scale $1: 24,000$.

1982, Special Studies Zones, Montara Mountain quadrangle: California Division of Mines and $\mathrm{Ge}$ ology, scale 1:24,000.

Carlson, Christine, 1984, Introduction, in Carlson, Christine, ed., Depositional facies of sedimentary serpentinite: selected examples from the Coast Ranges, California: Society of Economic Paleontologists and Mineralogists, Field Trip Guidebook No. 3, 1984 midyear meeting, San Jose, Calif., p. $73-76$

Chapman, R.H., and Bishop, C.C., 1968, Bouguer gravity map of California-San Francisco sheet: California Division of Mines and Geology, 3 p., scale $1: 250,000$.

Compton, R.R., 1966, Granitic and metamorphic rocks of the Salinian block, California Coast Ranges, in Bailey, E. H., ed., Geology of Northern California: California Division of Mines and Geology, Bulletin 190. p. 277-287.

Cowan, D.S., 1985, Structural styles in Mesozoic and Cenozoic mélanges in the western Cordillera of North America: Geological Society of America Bulletin, v. 96 , no. 4 , p. $451-462$.

Cummings, J.C., 1968, The Santa Clara Formation and possible post-Pliocene slip on the San Andreas Fault in central California, in Dickinson, W.R. and Grantz, Arthur, eds., Conference on geologic problems of San Andreas Fault system: Stanford University Publications in the Geological Sciences, v. XI, p. 191-206.

1972, The Santa Clara Formation on the San Francisco Peninsula, in Frizzell, Virgil, ed., Progress report on the USGS Quaternary studies in the San Francisco Bay area: Friends of the Pleistocene Guidebook, Oct. 6-8, 1972, p. 3-10.

Cummings, J.C., Touring, R.M., and Brabb, E.E., 1962, Geology of the northern Santa Cruz Mountains, California, in Geologic guide to the gas and oil fields of northern California, Pt. II: California Division of Mines and Geology Bulletin 181, p. 179-220.
Curtis, G.H., Evernden, J.F., and Lipson, J., 1958, age determination of some granitic rocks in California by the potassium-argon method: California Division of Mines Special Report 54, 16 p.

Darrow, R.K., 1963, Age and structural relationships of the Franciscan Formation in the Montara Mountain quadrangle: California Division of Mines and $\mathrm{Ge}$ ology Special Report 78, $23 \mathrm{p}$.

Dibblee, T.W., Jr., 1966a, Geology of the Palo Alto [15'] quadrangle, Santa Clara and San Mateo Counties, California: California Division of Mines and Geology Map Sheet 8, scale 1:62,500.

1966b, Evidence for cumulative offset on the San Andreas Fault in central California, in Bailey, E.H., ed., Geology of northern California: California Division of Mines and Geology Bulletin 190, p. 375384.

Donely, H.F., Wire, J.C., and Rowland, R.E., 1975, Geotechnical study; Geologic Fault hazard zone, City of Burlingame, California: Engineering Geology and Soils Engineering, Proceedings No. 13, p. 121-132 (Pocatello, Idaho).

Earth Sciences Associates, 1975, Geology and geologic and seismic hazards, City of San Carlos, California: Earth Sciences Associates, Palo Alto, California, unpublished report prepared for the City of San Carlos, 28 p., 3 figs.

Ellen, S.D., and Wieczorek, G.E., eds., 1988, Landslides, floods, and marine effects of the storm of January 3-5, 1982, in the San Francisco Bay region: U.S. Geological Survey Professional Paper 1434, 310 p., 14 pl.

Evernden, J.F., and Kistler, R.W., 1970, Chronology of emplacement of batholitic complexes in California and western Nevada: U.S. Geological Survey Professional Paper 623, 42 p.

Fairbanks, H.W., 1897, The geology of the San Francisco Peninsula: Journal of Geology, v. 5, p. 6376.

Fox, K.F., Jr., 1983, Mélanges and their bearing on Late Mesozoic and Tertiary subduction and interplate translation at the west edge of the North American plate: U.S. Geological Survey Professional Paper 1198, 42 p.

Galehouse, J.S., 1981, Theodolite measurements of creep rates on San Francisco Bay region Faults: San Francisco State Univ., Frederic Burk Foundation for Education, Semi-annual Technical Report, Contract No. 14-08-0001-19767, 34 p.

Graham, S.A., and Dickinson, W.R., 1978, Apparent offsets of on-land geologic features across the San Gregorio-Hosgri Fault trend, in Silver, E.A., and Normark, W.R., eds., San Gregorio-Hosgri Fault zone, California: California Division of Mines and Geology Special Report 137, p. 13-23.

Glen, William, 1959, Pliocene and lower Pleistocene of the western part of the San Francisco penin- 
sula: California University Publications in Geological Sciences, v. 36, no. 2, p. 147-198.

Haehl, H.L., and Arnold, Ralph 1904, The Miocene diabase of the Santa Cruz Mountains in San Mateo County: American Philosophical Society, Proceedings, v. 43, p. $15-53$.

Hall, N.T., 1966, Late Cenozoic stratigraphy between Mussel Rock and Fleishacker Zoo, San Francisco Peninsula: California Division of Mines and Geology, Mineral Information Service, v. 19, no. 11, p. S22-S25.

Harsh, P.W., 1977, Alinement array measurements on the San Andreas Fault in northern California and their tectonic significance [abs.]: Geological Society of America Abstracts with Programs, v. 9, no.4, p. 431.

Hay, O.P., 1927, The Pleistocene of the western region of North America and its vertebrated animals: Carnegie Institution of Washington, Publication No. 322B, 346 p., 12 pls.

Helley, E.J., and Lajoie, K.R., 1979, Geology and engineering properties of the flatland deposits, in Helley, E.J., Lajoie, K.R., Spangle, W.E., and Blair, M.L., 1979, Flatland deposits of the San Francisco Bay Region, California-their geology and engineering properties, and their importance to comprehensive planning: U.S. Geological Survey Professional Paper 943 , p. $14-68$, pl. 3 , scale $1: 125,000$.

Helley, E.J., Adam, D.P., and Burke, D.B., 1972, Late Quaternary stratigraphic and paleontological investigations in the San Francisco Bay area, in Frizzell, Virgil, ed., Progress report on the USGS studies in the San Francisco bay area: Friends of the Pleistocene Guidebook, Oct. 6-8, 1972, p. 19-29.

Helley, E.J., Lajoie, K.R., Spangle, W.E., and Blair, M.L., 1979, Flatland deposits of the San Francisco Bay Region, California-their geology and engineering properties, and their importance to comprehensive planning: U.S. Geological Survey Professional Paper 943, 87 p., 3 pls., scale 1:125,000.

Hensolt, W.H., and Brabb, E.E., 1990, Maps showing elevation of bedrock and implications for design of engineered structures to withstand earthquake shaking in San Mateo County, California: U.S. Geological Survey Open-File Report 90-496, map scale $1: 62,500$.

Howard, T.R., Baldwin, J.E., and Donley, H.F., 1988, Landslides in Pacifica, California, caused by the storm, in Ellen, S.D., and Wieczorek, G.F., eds., Landslides, floods, and marine effects of the storm of January 3-5, 1982, in the San Francisco Bay region: U.S. Geological Survey Professional Paper 1434, p. 163-183.

Hsu, K.J., 1968, Principles of mélanges and their bearing on the Franciscan-Knoxville paradox: Geological Society of America Bulletin, v. 79, p. 1063-1074.

Jack, R.N., 1969, Quaternary sediments at Montara, San Mateo County, California: California University, Berkeley, M. A. thesis, 131 p.
Kennedy, G.L., Lajoie, K.R., Blunt, D.J., and Mathieson, S.A., 1982, The Half Moon Bay terrace, San Mateo County, California, and the age of its Pleistocene invertebrate faunas: Western Society of Malacologists, Annual Report, v. 14, p. 11-12.

Lajoie, K.R., Weber, G.E., and Tinsley, J.C., 1972, Marine terrace deformation, San Mateo and Santa Cruz Counties, in Frizzell, Virgil, ed., Progress report on the USGS Quaternary studies in the San Francisco Bay area: Friends of the Pleistocene Guidebook, Oct. 6-8, 1972, p. 100-111.

Lajoie, K.R., Helley, E.J., Nichols, D.R., and Burke, D.B., 1974, Geologic map of unconsolidated and moderately consolidated deposits of San Mateo County, California: U.S. Geological Survey Miscellaneous Field Studies Map MF-575, scale 1:62,500.

Lawrence, W.B., 1924, A bit of earthquake damage: San Francisco Water, v. 3, no. 4, p. 13-16.

Lawson, A.C., 1893, The post-Pliocene diastrophism of the coast of southern California: University of California, Department of Geology Bulletin, v. 1, no. 4, p. $115-160$.

1895, Sketch of the geology of the San Francisco Peninsula: U.S. Geological Survey 15th Annual Report, p. 399-476.

1914, Description of the San Francisco district [California]: U.S. Geological Survey Geologic Atlas Folio, no. 193,24 p., 15 map sheets, scale $1: 62,500$.

Chairman,1908, The California earthquake of April 18, 1906-Report of the State Earthquake Investigation Commission: Carnegie Inst. Washington Pub. 87 , v. 1,451 p., atlas.

Leighton, F.B., and Associates, 1971, Geologic report of Seal Cove and Moss Beach area, County of San Mateo: Unpublished report on file in the San Mateo County Engineer's office, 78 p.

Louderback, G.D., 1937, Characteristics of active faults in the central Coast Ranges of California, with application to the safety of dams: Seismological Society of America Bulletin 27, no. 1, p. 1-27.

Mark, R.K., and Newman, E.B., 1988, Slope map of San Mateo County, California: U.S. Geological Survey Miscellaneous Investigations Series Map I-1257-J, scale $1: 62,500$.

McCulloch, D.S., 1989, Evolution of the offshore central California margin, in Winterer, E.L., Hussong, D.M., and Decker, R.W., eds., The Eastern Pacific Ocean and Hawaii: Boulder, Colo., Geological Society of America, The Geology of North America, v. N, p. 439-469.

McLaughlin, R.J., 1969, the Franciscan Series and Eocene(?) rocks west of San Carlos and Belmont, California: Unpublished student report, San Jose State University, 5 p., map scale 1:24,000.

Morgan, S.R., 1981a, Geology and petrography of the Paleocene strata at Devils Slide, San Mateo County, California: Bellingham, Wash., Western Washington University, MS thesis, $224 \mathrm{p}$. 
1981b, General geology of the Paleocene strata at Point San Pedro, San Mateo County, California, in Frizzell, Virgil, ed., Upper Cretaceous and $\mathrm{Pa}$ leocene turbidites, central California coast: Society of Economic Paleontologists and Mineralogists, Pacific Coast Section Field Trip 6, p. 13-19, 49-52.

Naeser, C.W., and Ross, D.C., 1976, Fission-track ages of sphene and apatite of granitic rocks of Salinian block, Coast Ranges, California: U.S. Geological Survey Journal of Research, v. 4, no. 4, p. 415-420.

Nichols, D.R., and Wright, N.A., compilers, 1971, Preliminary map of historic margins of marshlands, San Francisco Bay, California: U.S. Geological Survey Open-File Report 71-216, map scale 1:125,000.

Nilsen, T.H., and Brabb, E.E., eds., 1979, Geology of the Santa Cruz Mountains, California: Geological Society of America Cordilleran Section field trip guidebook, no. 7, $97 \mathrm{p}$.

Nilsen, T.H., and Yount, J.C., 1981, Sedimentology of the Paleocene strata of Point San Pedro, California, in Frizzell, Virgil, ed., Upper Cretaceous and Paleocene turbidites, central California coast: Society of Economic Paleontologists and Mineralogists, Pacific Section Field Trip 6, p. 31-48.

Pampeyan, E.H., 1970, Geologic map of the Palo Alto 7-1/2-minute quadrangle, San Mateo and Santa Clara Counties, California: U.S. Geological Survey OpenFile Map 70-254, scale 1:12,000.

1975, Geologic map of the San Andreas Fault in San Andreas Lake, San Mateo County, California: U.S. Geological Survey Miscellaneous Field Studies Map MF-652, scale 1:6,000.

1981a, Geologic map of the Montara Mountain quadrangle, San Mateo County, California: U.S. Geological Survey Open-File Report 81-451, 14 p., map scale $1: 12,000$.

1981b, Geology and former shoreline features of the San Mateo 7-1/2-minute quadrangle, San Mateo County, California: U.S. Geological Survey OpenFile Report 81-839, 12 p., map scale 1:24,000.

1983, Map showing the 1906 San Andreas Fault trace and related features in the Montara Mountain and San Mateo 7-1/2-minute quadrangles, San Mateo County, California: U.S. Geological Survey Miscellaneous Field Studies Map MF-1488, scale 1:24,000.

1986, Effects of the 1906 earthquake on the Bald Hill outlet system, San Mateo County, California: Bulletin of the Association of Engineering Geologists, v. XXII, no. 2, p. 197-208.

1993, Geologic map of the Palo Alto and part of the Redwood Point 7-1/2' quadrangles, San Mateo and Santa Clara Counties, California: U.S. Geological Survey Miscellaneous Investigations Series Map I-2371, scale $1: 24,000$.

Parkin, E.J., 1965, Olema and Crystal Springs Lake, California: study of earth movement determined by triangulation, 1906-1963, in U.S. Department of Commerce (1973), Reports on geodetic measurements of crustal movements, 1906-1971: U.S.
Department of Commerce, Rockville, MD, art. 39, $12 \mathrm{p}$.

Perkins, J.B., 1987, Maps showing cumulative damage potential from earthquake ground shaking, San Mateo County, California: U.S. Geological Survey Miscellaneous Investigations Series Map I-1257-I, scale $1: 62,500$.

Potbury, S.S., 1932, A Pleistocene flora from San Bruno, San Mateo County, California, in Studies of the Pleistocene palaeobotany of California: Carnegie Institution of Washington, Contributions to Palaeontology, Publication No. 415 (1934), p. 2544.

Reed, R.D., 1933, Geology of California: Tulsa, Okla., American Association of Petroleum Geologists, 355 p.

Riedel, W.R., and Schlocker, Julius, 1956, Radiolaria from the Franciscan group, Belmont, California: Micropaleontology, v. 2, no. 4, p. 357-360.

Robbins, S.L., Roberts, C.W., and Chapman, R.H., 1982, Bouguer gravity map of southern San Francisco Bay region, California: U.S. Geological Survey Miscellaneous Field Studies Map MF-780-C, scale 1:125,000.

Ross, D.C., 1972, Petrographic and chemical reconnaissance of some granitic and gneissic rocks near the San Andreas Fault from Bodega Head to Cajon Pass: U.S. Geological Survey Professional Paper 698, 92 p.

1984, Possible correlations of basement rocks across the San Andreas, San Gregorio-Hosgri, and RinconadaReliz-King City faults, California: U.S. Geological Survey Professional Paper 1317, 37 p.

San Francisco Public Utilities Commission, 1924, Photo D-877, view northeast along old Locks Creek pipeline in Lower Crystal Springs Reservoir, 8/25/24; photo D-879, view southwest along old Locks Creek pipeline in Lower Crystal Springs Reservoir, 8/25/24: Photographs in archives of the San Francisco Public Utilities Commission, San Francisco, California.

1931, Photo D-1695, view east-southeast of Hayward dam, Crystal Springs dam in background, 3/13/31; photo D-1698, view northeast across Hayward dam: Photographs in archives of the San Francisco Public Utilities Commission, San Francisco, California.

Sarna-Wojcicki, A.M., Meyer, C.E., Bowman, H.R., Hall, N.T., Russell, P.C., Woodward, M.J., and Slate, J.L., 1985, Correlation of Rockland ash bed, a 400,000year-old stratigraphic marker in northern California and western Nevada, and implications for middle Pleistocene paleogeography of central California: Quaternary Research, v. 23, p. 236-257.

Schlocker, Julius, and Bonilla, M.G., 1962, Field trip 4, San Francisco Peninsula, in Bowen, O.E., Jr., ed., Geologic guide to gas and oil fields of northern California: California Division of Mines and Geology Bulletin 181, p. 399-406.

Schussler, Hermann, 1906, The water supply of San Francisco, California, before, during and after the earthquake of April 18, 1906, and the subsequent 
conflagration: New York, Martin Brown Press, 103 p.

Smith, D.D., 1960, The geomorphology of part of the San Francisco Peninsula, California: Stanford, Calif., Stanford University Ph.D. dissertation, 356 p.

Sorg, D.H. and McLaughlin, R.J., 1975, Geologic map of the Sargent-Berrocal Fault Zone between Los Gatos and Los Altos Hills, Santa Clara County, California: U.S. Geological Survey Miscellaneous Field Studies Map MF-643, scale 1:24,000.

Streckeisen, A.L., 1973, Plutonic rocks: classification and nomenclature recommended by the IUGS Subcommission on the Systematics of Igneous Rocks: Geotimes, v. 18 , no. 10 , p. $26-30$.

Steiger. R.H., and Jager, E., compilers, 1977, Subcommission on geochronology; convention on the use of decay constants in geo- and cosmochronology: Earth and Planetary Science Letters, v. 36, no. 3, p. 359-362.

Tarduno, J.A., Blake, M.C., and Sliter, W.V., 1991, Stratigraphy and structure of the Permanente terrane, southern San Francisco Bay area [abst.]: Geological Society of America, Abstracts with Programs, v. 23, no. 2, p. 102.

Thomson, J.M., and Evernden, J.F., 1986, Map showing predicted shaking intensities of an earthquake in San Mateo County, California, comparable in magnitude to the 1906 San Francisco earthquake: U.S. Geological Survey Miscellaneous Investigations Series Map 1-1257-H, scale 1:62,500.

Tinsley, J.C., 1972, Sea Cliff retreat as a measure of coastal erosion, San Mateo county, California, in Frizzell, Virgil, ed., Progress report on the USGS Quaternary studies in the San Francisco Bay area: Friends of the Pleistocene Guidebook, Oct. 6-8, 1972, p. 56-83a.

U.S. Coast Survey, 1853a, Map of part of the coast of California from Point San Pedro northward: U.S. Coast Survey, Register No. 395, scale 1:10,000. 1853b, San Francisco Bay between Point San Matheo [Coyote Point] and Guano Island: U.S. Coast Survey, Register No. 433, scale 1:10,000.

1854, Untitled map of shoreline area between Point San Matheo [Coyote Point] and Millbrae: Register No. 460, scale 1:10,000.

1857a, San Francisco Bay [between San Francisquito Creek and Guano Island]: U.S. Coast Survey, Register No. 664, scale 1:10,000.

1857b, San Francisco Bay [between Redwood City and Belmont]: U.S. Coast Survey, Register No. 665, scale 1:10,000.

1867, Map showing approaches to San Francisco, California, for use of Engineering Department, U.S. Army: U.S. Coast Survey, Register No. 1067, scale 1:10,000.

1868, Map showing approaches to San Francisco California, for use of Engineer Department, U. S. Army, Millbrae and vicinity: U.S. Coast Survey, Register No. 1068, scale 1:10,000.
1869, San Francisco Peninsula: U.S. Coast Survey, Register No. 3055, scale 1:40,000.

U.S. Geological Survey, 1899, San Mateo quadrangle: U.S. Geological Survey 15-minute topographic quadrangle, edition of 1899 , surveyed in 1892 , scale $1: 62,500$.

1915, San Mateo quadrangle: U.S. Geological Survey 15-minute topographic quadrangle, edition of 1915 , surveyed in 1892 , culture revised in 1914 , scale $1: 62,500$.

Vanderhurst, W.L., Cummings, J.C., and Anderson, D.W., 1982, The Santa Clara Formation as a record of late Cenozoic uplift of the Santa Cruz Mountains, Santa Clara County, California, in Ingersoll, R.V., and Woodburne, M.O., eds., Cenozoic nonmarine deposits of California and Arizona: Los Angeles, Pacific Section of Economic Paleontologists and Mineralogists, p. 23-33.

Ver Planck, W.E., 1958, salt in California: California Division of Mines Bulletin 175, $168 \mathrm{p}$.

Wakabayashi, John, and Moores, E.M., 1988, Evidence for the collision of the Salinian block with the Franciscan subduction zone, California: Journal of Geology, v. 96, p. 245-253.

Watts, W.L., 1888, San Mateo County, in Eighth Annual Report to the State Mineralogist: California Mining Bureau, p. 533-536.

Weber, G.E., and Lajoie, K.R., 1980, Map of Quaternary faulting along the San Gregorio Fault zone, San Mateo and Santa Cruz Counties, California: U.S. Geological Survey Open-File Report 80-907, scale $1: 24,000$.

Wentworth, C.M., Ellen, Stephen, Frizzell, V.A., Jr., and Schlocker, Julius, 1985, Map of hillside materials and description of their engineering character, San Mateo County, California: U.S. Geological Survey Miscellaneous Investigations Series Map I-1257-D, scale $1: 62,500$.

Wesson, R.L., Helley, E.J., Lajoie, K.R., and Wentworth, C.M., 1975, Faults and future earthquakes, in Borcherdt, R.D., ed., Studies for seismic zonation of the San Francisco Bay region: U.S. Geological Survey Professional Paper 941-A, p. A5-A30.

Wieczorek, G.F., Wilson, R.C., and Harp, E.L., 1985, Map showing slope stability during earthquakes in San Mateo County, California: U.S. Geological Survey Miscellaneous Investigations Series Map I-1257-E, scale $1: 62,500$.

Willis, Bailey, 1938, San Andreas rift, California: Journal of Geology, v. 46, no. 6, p. 793-827.

Woodward-Lundgren and Associates, 1971, Preliminary geologic study of the Murray Ranch (Sugarloaf) development: Unpublished report prepared for the Cargus Corporation, on file in the Planning Commission office, City of San Mateo, $5 \mathrm{p}$.

Youd, T.L., and Perkins, J.B., 1987, Map showing liquefaction susceptibility of San Mateo County, California: U.S. Geological Survey Miscellaneous Investigations Series Map I-1257-G, scale 1:62,500. 
